Check for updates

Cite this: RSC Adv., 2019, 9, 40118

Received 11th November 2019

Accepted 21st November 2019

DOI: 10.1039/c9ra09379f

rsc.li/rsc-advances

\section{Exploiting a multicomponent domino reaction strategy for the tailoring of versatile environmentally sensitive fluorophore-based nicotinonitriles incorporating pyrene and fluorene moieties $\dagger$}

\begin{abstract}
Essam M. Hussein, (DD ab Nizar El Guesmi ${ }^{\mathrm{ac}}$ and Saleh A. Ahmed (DD *ab
A simplistic and highly effective protocol for the synthesis of a new class of poly-functionalized innovative nicotinonitriles incorporating pyrene and/or fluorene moieties has been developed through the domino four-component condensation reaction of 1-(pyren-1-yl)ethanone/1-(9H-fluoren-2-yl)ethanone, numerous aromatic aldehydes, and 3-oxo-3-(pyren-1-yl)propanenitrile/3-(9H-fluoren-2-yl)-3oxopropanenitrile and ammonium acetate in acetic acid as a reaction medium. The advantages of this approach are the short reaction time, excellent yield, and the easy experimental workup that affords substrate diversity and operative competence under metal-free reaction conditions for the formation of $\mathrm{C}-\mathrm{C}$ and $\mathrm{C}-\mathrm{N}$ bonds. The substituent effects on the photophysical property-based absorption and the emission of the synthesized compounds in dichloromethane have been well-investigated. Strong absorption quenching of around $100 \mathrm{~nm}$ was observed when substitution of the benzene ring at the $\mathrm{C}_{4}$ position of the pyridine moiety occurred with an electron-donating $\left(-\mathrm{N}\left(\mathrm{CH}_{3}\right)_{2}\right)$ group. All of the newly synthesized nicotinonitrile derivatives showed strong blue-green fluorescence emission with maxima in the range between 420-630 $\mathrm{nm}$. These highly pronounced emission spectra will help this family of compounds to find application in many areas and the field of materials science.
\end{abstract}

\section{Introduction}

Carbon-carbon and carbon-nitrogen bond-forming reactions are amongst the most important transformations in organic synthesis. $^{1}$ Dissimilar conventional multistep reactions, enhanced efficacy, higher reaction yields, atom economy, shorter reaction times, ecologically benign reactions, amended selectivity, and lower costs can be accomplished using multicomponent reactions (MCRs), which are influential and helpful tools in modern medicinal chemistry, providing easy access to an enormous number of structurally connected drug-like heterocyclic compounds. ${ }^{2-5}$ Poly-functionalized nitrogencontaining heterocycles are essential structural components in numerous natural products and synthetic drugs. They have great applications in drug discovery and are beneficial and

${ }^{a}$ Chemistry Department, Faculty of Applied Science, Umm Al-Qura University, 21955 Makkah, Saudi Arabia.E-mail: saahmed@uqu.edu.sa

${ }^{b}$ Department of Chemistry, Faculty of Science, Assiut University, 71516 Assiut, Egypt. E-mail:saleh.a.ahmed@aun.edu.eg; saleh_63@hotmail.com

'Département de Chimie, Faculté des Sciences de Monastir, Avenue de L'Environnement, 5019 Monastir, Tunisia

$\dagger$ Electronic supplementary information (ESI) available. See DOI: $10.1039 /$ c9ra09379f useful materials. ${ }^{6-8}$ Pyridine derivatives substituted at the 2,4 , and 6 positions have an extensive range of applications, most of which are based upon their unique photophysical properties. The applications of these compounds comprise photographic acid-mediated imaging media, ${ }^{9}$ thermal recording materials, ${ }^{10}$ photo-curable assembly for stereolithography, laser dyes ${ }^{11}$ and ion probes. ${ }^{12,13}$ In the last few decades, design and synthesis of materials with light-emitting properties has emerged as an exciting topic of research in both academic and industrial applications. ${ }^{14}$ Furthermore, pyrene is a $\pi$-extensive conjugated polynuclear aromatic hydrocarbon, which was recently considered as being one of the most extensively studied organic fragments in the field of photochemistry and photophysics. The extremely fluorescence properties of pyrene mean it is the first choice fluorophore in both fundamental and applied photochemical and photophysical research. ${ }^{15-21}$ As its monomer emission typically appears at $370-420 \mathrm{~nm}$ and it is a distinguishing violet color, the pyrene moiety is considered to be one of the most beneficial assembly moieties for the construction of fluorogenic chemosensors that are frequently used for necessary chemical applications. ${ }^{22}$ Pyrene derivatives have been extensively used in many applications as fluorescent probes $^{23}$ and fluorescent sensors. ${ }^{24,25}$ On the other hand, fluorene derivatives, which are less important than pyrene, are adaptable 
moieties which are used in a wide range of synthetic purposes. ${ }^{26}$ Amongst the fluorophores, fluorene derivatives have reasonable quantum yields and are less bulky than other frequently used fluorophores, such as fluorescein and cyanine dyes. ${ }^{27}$ Nevertheless, fluorene-based polymers and copolymers are brilliant candidates for optical and electrical applications because they display extraordinary chemical/thermal stability, outstanding fluorescence quantum yields and consequently are commonly used in organic light-emitting diodes, flat panel displays and in solar cells. ${ }^{28-30}$ In the last decay, numerous approaches have been developed by many researchers for the synthesis of 2,4,6trisubstituted nicotinonitriles. ${ }^{31-37}$ However, no reports were found of the synthesis of a single molecular structure with these three units (pyrene, nicotinonitrile and fluorene). Based on the above described findings, and in continuation of our ongoing research interest which deals with the synthesis of novel environment-sensitive fluorophores ${ }^{38,39}$ and the development of efficient, low-cost and simple new methodologies for the synthesis of nitrogen-containing heterocyclic compounds through MCRs, ${ }^{40-44}$ a simple, straight-forward and efficient procedure for the synthesis of novel highly functionalized nicotinonitriles incorporating pyrene and/or fluorene moieties in good to excellent yields has been achieved. Yields of up to $98 \%$ via a one-pot four-component condensation reaction of 1(pyren-1-yl)ethanone/1-(9H-fluoren-2-yl)ethanone, various aromatic aldehydes, 3-(9H-fluoren-2-yl)-3-oxopropanenitrile/3oxo-3-(pyren-1-yl)propanenitrile and ammonium acetate in refluxing acetic acid were successfully attained. The aim behind this work is to develop convenient approaches to numerous novel fluorophores based on nicotinonitrile as fluorescent type molecules containing pyrene and/or fluorene moieties and study their emission spectral characteristics owing to the promising physiological and fluorescent properties of these kind of molecules.

\section{Results and discussion}

\section{Synthetic strategy}

The choice of appropriate reaction conditions was of key importance for effectual synthesis. Initially, we began our present investigation of the four-component one-pot reaction with 1-acetylpyrene (1a), benzaldehyde (2a), 3-(9H-fluoren-2-yl)3-oxopropanenitrile (3a), and ammonium acetate (4) which were selected as a model reaction (Scheme 1).

To optimize the reaction conditions, a series of experiments were implemented and the effects of different catalysts and

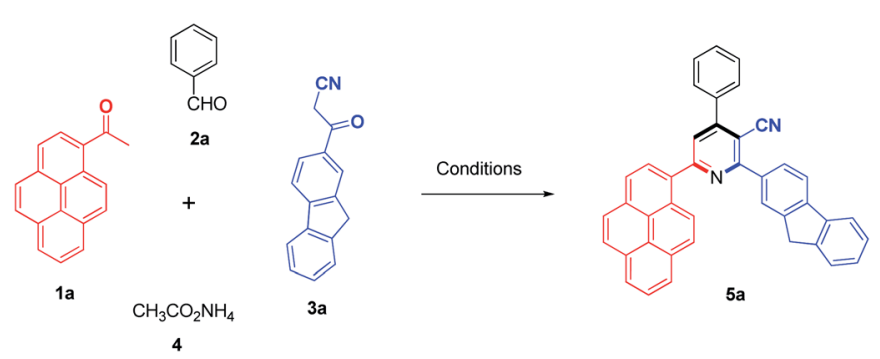

Scheme 1 Model reaction.
Table 1 The effects of catalysts and solvents on the yield of the model reaction $^{a}$

\begin{tabular}{|c|c|c|c|c|}
\hline Entry & Catalyst (mol\%) & Solvent & Time (h) & Yield (\% \\
\hline 1 & - & $\mathrm{MeOH}$ & 24 & - \\
\hline 2 & - & EtOH & 24 & - \\
\hline 3 & - & 2-Propanol & 24 & - \\
\hline 4 & - & DMF & 24 & - \\
\hline 5 & - & Dioxane & 24 & - \\
\hline 6 & $\mathrm{~K}_{2} \mathrm{CO}_{3}(30)$ & EtOH & 15 & 12 \\
\hline 7 & Piperidine (30) & $\mathrm{EtOH}$ & 15 & 16 \\
\hline 8 & $\mathrm{ZnCl}_{2}(30)$ & $\mathrm{EtOH}$ & 15 & 21 \\
\hline 9 & $p$-TsOH (30) & EtOH & 10 & 35 \\
\hline 10 & $\mathrm{HCO}_{2} \mathrm{H}(30)$ & EtOH & 12 & 34 \\
\hline 11 & $\mathrm{AcOH}(30)$ & EtOH & 7 & 43 \\
\hline 12 & $\mathrm{AcOH}(30)$ & $\mathrm{MeOH}$ & 7 & 38 \\
\hline 13 & $\mathrm{AcOH}(30)$ & 2-Propanol & 8 & 37 \\
\hline 14 & $\mathrm{AcOH}(30)$ & DMF & 7 & 39 \\
\hline 15 & $\mathrm{AcOH}(30)$ & Dioxane & 10 & 19 \\
\hline 16 & $\operatorname{AcOH}(50)$ & EtOH & 7 & 50 \\
\hline 17 & $\mathrm{AcOH}(100)$ & EtOH & 7 & 66 \\
\hline 18 & - & $\mathrm{EtOH} / \mathrm{AcOH}(1 / 1)$ & 6 & 70 \\
\hline 19 & - & EtOH/AcOH $(2 / 3)$ & 6 & 79 \\
\hline 20 & - & $\mathrm{EtOH} / \mathrm{AcOH}(1 / 4)$ & 5 & 86 \\
\hline 21 & - & AcOH & 4 & 94 \\
\hline
\end{tabular}

${ }^{a}$ Reaction conditions: 1-acetylpyrene (1a, $\left.1.0 \mathrm{mmol}\right)$, benzaldehyde (2a, $1.0 \mathrm{mmol}), 3$-(9H-fluoren-2-yl)-3-oxopropanenitrile (3a, $1.0 \mathrm{mmol}$ ), ammonium acetate $(4,3.0 \mathrm{mmol})$, solvent $(10 \mathrm{~mL}) /$ reflux.

solvents at the same reflux temperature on the yield of the model reaction was investigated (Table 1). First of all, it should be mentioned that the model reaction in the absence of a catalyst was accomplished in different solvents such as methanol $(\mathrm{MeOH})$, ethanol (EtOH), 2-propanol, dimethylformamide (DMF) and dioxane, but it failed to afford the desired product $\mathbf{5 a}$ even after increasing the reaction time to $24 \mathrm{~h}$ (Table 1, entries 1-5). Then, the model reaction was carried out in the presence of basic catalysts such as potassium carbonate $\left(\mathrm{K}_{2} \mathrm{CO}_{3}\right)$ and piperidine in ethanol as a solvent, which led to the formation of product $5 \mathrm{a}$ in a low yield (12 and 16\%), respectively (Table 1 , entries 6, 7).

However, the yield was enhanced to $21-43 \%$ when acidic catalysts such as zinc chloride $\left(\mathrm{ZnCl}_{2}\right), p$-toluenesulfonic acid ( $p$-TsOH), formic acid $\left(\mathrm{HCO}_{2} \mathrm{H}\right)$ and acetic acid $(\mathrm{AcOH})$ were used, as presented in Table 1 (entries 8-11). Amongst all of the acids used, acetic acid was found to be the best catalyst with

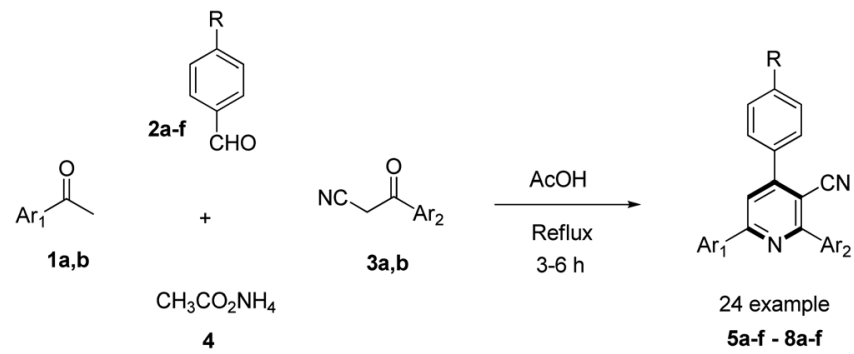

Scheme 2 The synthesis of novel poly-functionalized nicotinonitriles containing pyrene and/or fluorene moieties $5 a-f-8 a-f$. 
Table 2 The scope of the reaction: synthesis of 2-(9H-fluoren-2-yl)-4-aryl-6-(pyren-1-yl)nicotinonitriles $5 a-f^{a}$

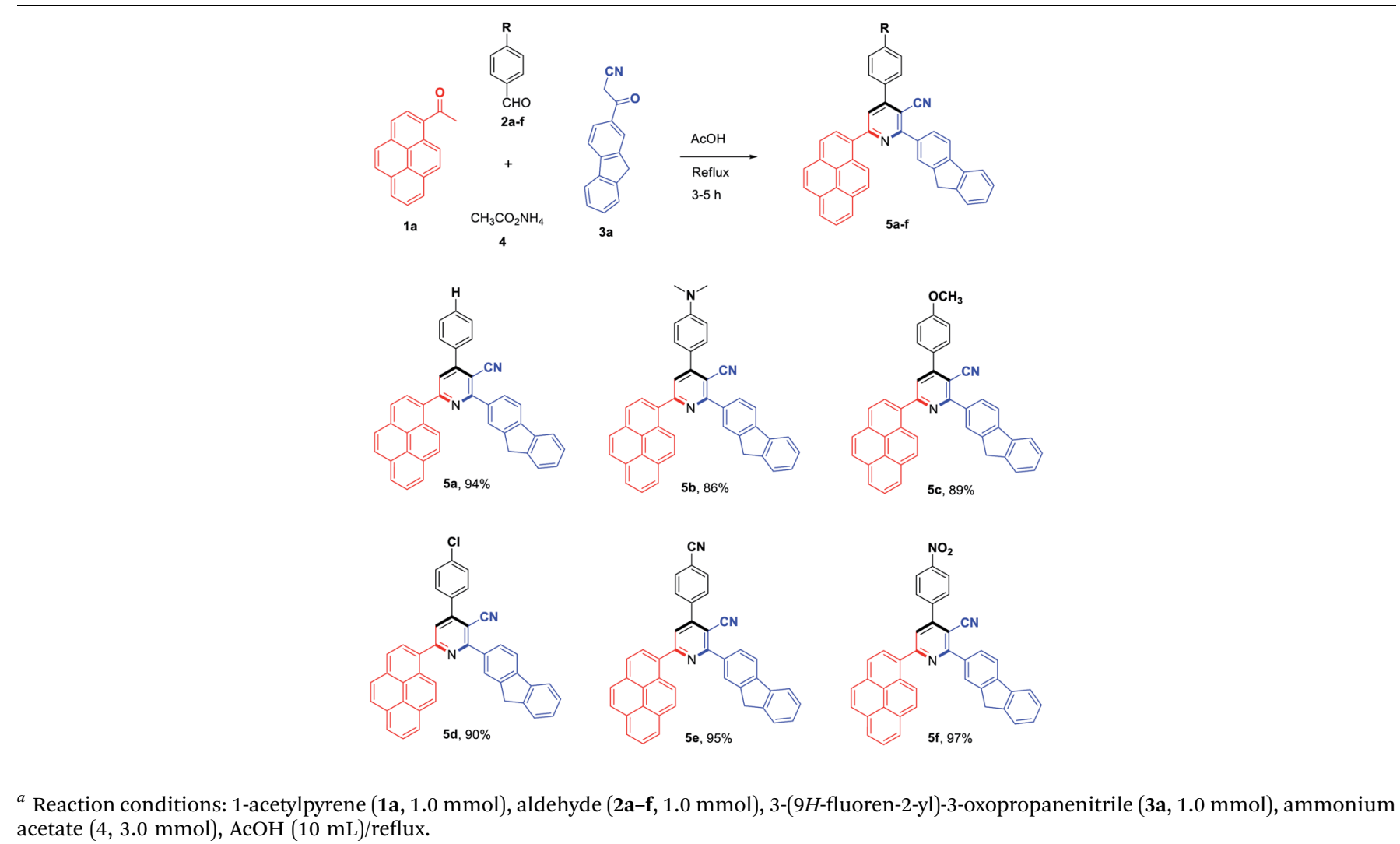
acetate $(4,3.0 \mathrm{mmol}), \mathrm{AcOH}(10 \mathrm{~mL}) /$ reflux.

regard to the isolated yield (Table 1 , entry 11 ). These observations encouraged us to explore the catalytic proficiency of $\mathrm{AcOH}$ in other solvents such as $\mathrm{MeOH}, 2$-propanol, DMF, and dioxane, but no improvement in the yield of the target product 5a was observed (Table 1, entries 12-15). Furthermore, we observe that the yields of $5 \mathbf{a}$ were distinctly affected by the amount of $\mathrm{AcOH}$ (Table 1, entries 16-21). It was found that when the amount of acetic acid was increased, the desired product 5 a was isolated in a significantly higher yield. Excitingly, we observed that acetic acid also operated as the best reaction medium compared with the other solvents (Table 1, entry 21) and the reaction proceeded smoothly affording the target product $\mathbf{5 a}$ in an excellent yield (94\%) in a short reaction time $(4 \mathrm{~h})$. According to the results obtained, it is clear that the reaction proceeds very smoothly with a high product yield in refluxing acetic acid as the reaction media.

To evaluate the scope and generality of the optimized reaction conditions, a wide range of aromatic aldehydes ketones $\mathbf{2 a -}$ 2f were selected to undergo this four-component cyclocondensation reaction with acyl derivatives such as 1-acetylpyrene (1a) and 2-acetylfluorene (1b). Additionally, 3- $(9 H-$ fluoren-2-yl)-3-oxopropanenitrile (3a) and 3-oxo-3-(pyren-1-yl) propanenitrile $(\mathbf{3 b})$ were found to be compatible under the optimized reaction conditions, leading to the formation of novel highly functionalized nicotinonitriles incorporating pyrene and/or fluorene moieties (Scheme 2).
All reactions proceeded smoothly to afford the target products 5a-f-8a-f in good to excellent yields (75-98\%) and the obtained results are summarized in Tables $2-5$. The aromatic aldehydes used in this study were deliberately selected to tolerate either electron-donating substituents (such as $\mathrm{N}\left(\mathrm{CH}_{3}\right)_{2}$ and $\mathrm{OCH}_{3}$ ) or electron-withdrawing substituents (such as $\mathrm{Cl}, \mathrm{CN}$ and $\mathrm{NO}_{2}$ ) to give noteworthy changes in their photophysical properties. Generally, the reactions were sufficiently clean and no side products were detected (TLC-controlled). In all cases, the reactions proceeded competently in acetic acid as a reaction media in refluxing conditions.

The chemical structures of all of the novel synthesized compounds 5a-f-8a-f were well-confirmed by means of spectroscopic techniques such as Fourier transform infrared spectroscopy (FT-IR), ${ }^{1} \mathrm{H} \quad \mathrm{NMR},{ }^{13} \mathrm{C} \quad \mathrm{NMR}$, and ${ }^{13} \mathrm{C}$ distortionless enhancement by polarization transfer (DEPT)135 data (c.f. Experimental section and ESI $\dagger$ ). The FT-IR spectra of compounds $\mathbf{5 a - f - 8 a - f}$ showed the presence of characteristic absorption bands at 2218-2199 and 1615$1610 \mathrm{~cm}^{-1}$ corresponding to the cyano and $\mathrm{C}=\mathrm{N}$ groups, respectively. Furthermore, to fully confirm the chemical structures of the products, intensive $1 \mathrm{D}\left({ }^{1} \mathrm{H},{ }^{13} \mathrm{C}\right.$, and DEPT135) NMR were conducted in $\mathrm{CDCl}_{3}$. Surprisingly, the ${ }^{1} \mathrm{H}$ NMR spectra of the fluorene-containing nicotinonitrile derivatives $5 \mathbf{a}-\mathbf{f}$ and $7 \mathbf{a}-\mathbf{f}$ revealed that the $\mathrm{sp}^{3} \mathrm{CH}_{2}$ protons of the fluorene moiety showed an "AB" spin pattern at $\delta_{\mathrm{H}} 4.06-3.88$ and 4.09-3.95 ppm, respectively. It should be emphasized that 
Table 3 The scope of the reaction: synthesis of 4-aryl-2,6-di(pyren1-yl)nicotinonitriles $6 a-f^{a}$

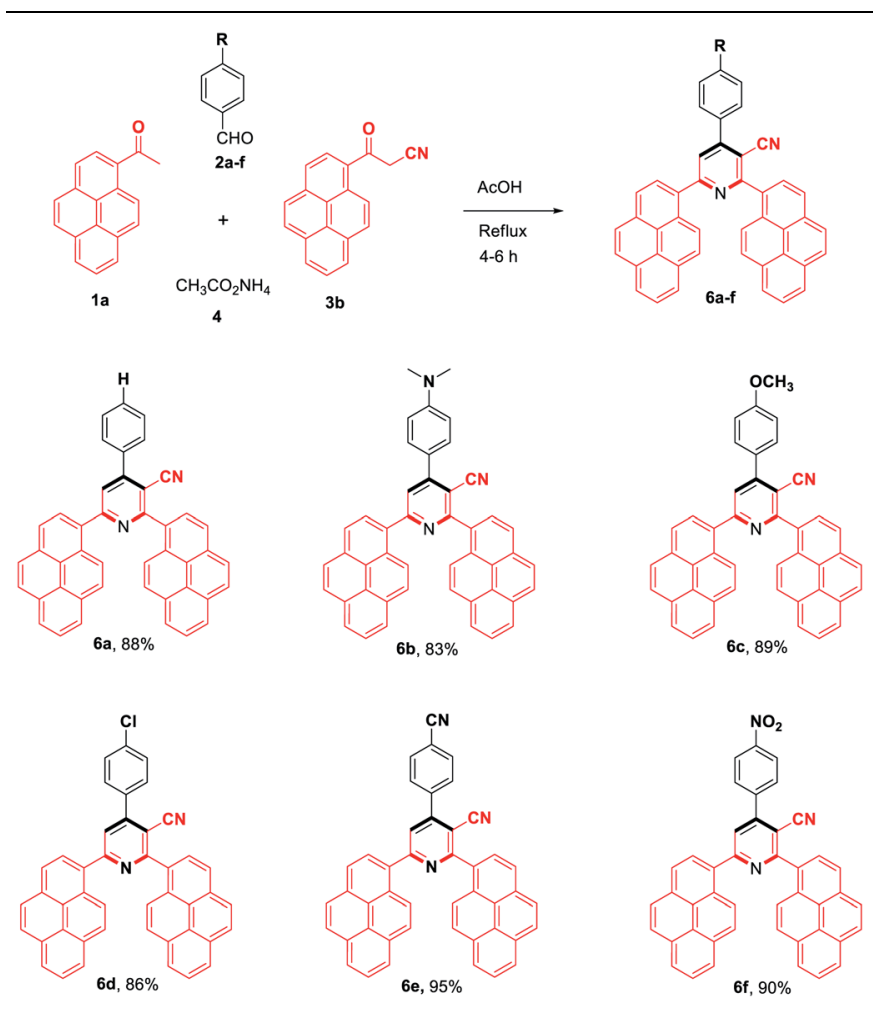

${ }^{a}$ Reaction conditions: 1 -acetylpyrene (1a, $\left.1.0 \mathrm{mmol}\right)$, aldehyde (2a-f, 1.0 $\mathrm{mmol}$ ), 3-oxo-3-(pyren-1-yl)propanenitrile (3b, $1.0 \mathrm{mmol}$ ), ammonium acetate $(4,3.0 \mathrm{mmol})$, AcOH $(10 \mathrm{~mL}) /$ reflux.

the coupling constants $\left({ }^{2} J_{\mathrm{HH}}\right)$ in the $\mathrm{CH}_{2}$ group (ranging from -21.5 to -35.5 and -19.0 to $-24.0 \mathrm{~Hz}$, respectively) show some variations and unusually higher absolute values. This observation may be concisely elucidated based on the following two facts: (a) the ${ }^{2} J_{\mathrm{HH}}$ coupling constant becomes more negative when a $\mathrm{CH}_{2}$ group is attached to a $\pi$-acceptor such as carbonyl, imino, or cyano group or conjugated with aryl, alkene and alkyne substituents, as the $\mathrm{H}-\mathrm{C}-\mathrm{H}$ angle is decreased and ${ }^{2} J_{\mathrm{HH}}$ coupling constant becomes more negative (larger); ${ }^{45}$ and (b) the negative mesomeric effect of the cyano group attached to the pyridine ring decreases the electron density especially at the 2-position, and sequentially, it may act as a $\pi$-acceptor group.

For example, analysis of the ${ }^{13} \mathrm{C}$ and ${ }^{13} \mathrm{C}$-DEPT-135 NMR spectra of $\mathbf{5 a}$ in $\mathrm{CDCl}_{3}$ indicated the presence of 38 signals $(22$ aromatic $\mathrm{CH}$ signals, 14 aromatic quaternary carbons, one cyano carbon, and one methylene carbon). The characteristic signals at $\delta 162.9,104.2$, and $36.9 \mathrm{ppm}$ correspond to the $\mathrm{C}=$ $\mathrm{N}$, cyano, and methylene carbons, respectively. In the ${ }^{1} \mathrm{H}$ NMR spectrum, the proton signals were revealed, a doublet signal at $\delta 8.58 \mathrm{ppm}\left({ }^{3} J=6.5 \mathrm{~Hz}\right)$ for the $\mathrm{C}_{2}-\mathrm{H}$ of the pyrene moiety, this shows the presence of methylene protons as a doublet $\left({ }^{2} J_{\mathrm{HH}}=35.5 \mathrm{~Hz}\right)$ at $4.00 \mathrm{ppm}$, and the remaining 21 aromatic protons appear in the expected region at $8.33-7.38 \mathrm{ppm}$. On
Table 4 The scope of the reaction: synthesis of 2,6-di(9H-fluoren-2yl)-4-(aryl)nicotinonitriles $7 a-f^{a}$

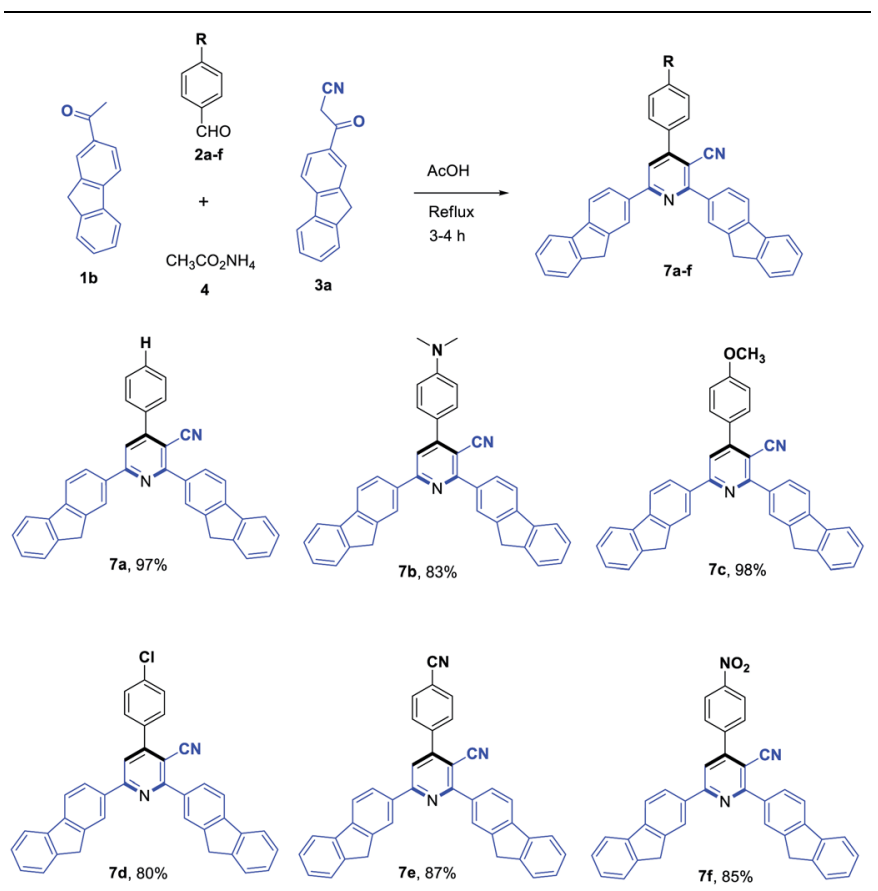

${ }^{a}$ Reaction conditions: 2-acetylfluorene (1b, $\left.1.0 \mathrm{mmol}\right)$, aldehyde (2a-f, $1.0 \mathrm{mmol}), 3$-(9H-fluoren-2-yl)-3-oxopropanenitrile (3a, $1.0 \mathrm{mmol}$ ), ammonium acetate $(4,3.0 \mathrm{mmol})$, AcOH $(10 \mathrm{~mL}) /$ reflux.

the other hand, the ${ }^{13} \mathrm{C}$ and ${ }^{13} \mathrm{C}$-DEPT-135 NMR spectra of $6 \mathbf{a}$ in $\mathrm{CDCl}_{3}$ revealed the presence of 29 signals in the region at 164.0-117.7 ppm (22 aromatic $\mathrm{CH}$ signals and 7 aromatic quaternary carbons) and the cyano carbon resonated at $\delta 107.5 \mathrm{ppm}$. The ${ }^{1} \mathrm{H}$ NMR spectrum showed the signals corresponded to 24 aromatic protons in the region at 8.59$7.15 \mathrm{ppm}$.

The postulated mechanism for the formation of the desired products $\mathbf{5 a}-\mathbf{f}-\mathbf{8 a}-\mathbf{f}$ is proposed in Scheme 3 . Acetyl compound 1 condensed with ammonium acetate to form the corresponding imine intermediate $\mathbf{A}$, a Knoevenagel condensation reaction between nitrile derivative 3 and aromatic aldehyde 2 afforded the intermediate $\mathbf{B}$ which can act as a Michael receptor. Then, a 1,4-Michael addition reaction between intermediates $\mathbf{A}$ and $\mathbf{B}$ followed by intramolecular cyclization via nucleophilic attack of the amino group to the carbonyl group gave the dihydro intermediate C. Dehydration of the intermediate $\mathbf{C}$ afforded the corresponding intermediate $\mathbf{D}$, which could finally undergo dehydrogenation to give the desired products 5-8.

The proposed mechanistic pathway shown in Scheme 3 was experimentally supported by the stepwise synthesis of 2(9H-fluoren-2-yl)-4-phenyl-6-(pyren-1-yl)nicotinonitrile (5a) under the optimized conditions via the reaction of benzaldehyde (2a) and 3-(9H-fluoren-2-yl)-3-oxopropanenitrile (3a) to afford the corresponding 2-(9H-fluorene-2-carbonyl)-3phenylacrylonitrile (Michael acceptor), which was isolated 
Table 5 The scope of the reaction: synthesis of 6-(9H-fluoren-2-yl)-4-phenyl-2-(pyren-1-yl)nicotinonitrile $8 \mathrm{a}-\mathrm{f}^{a}$

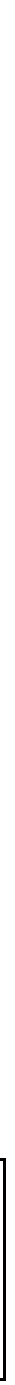

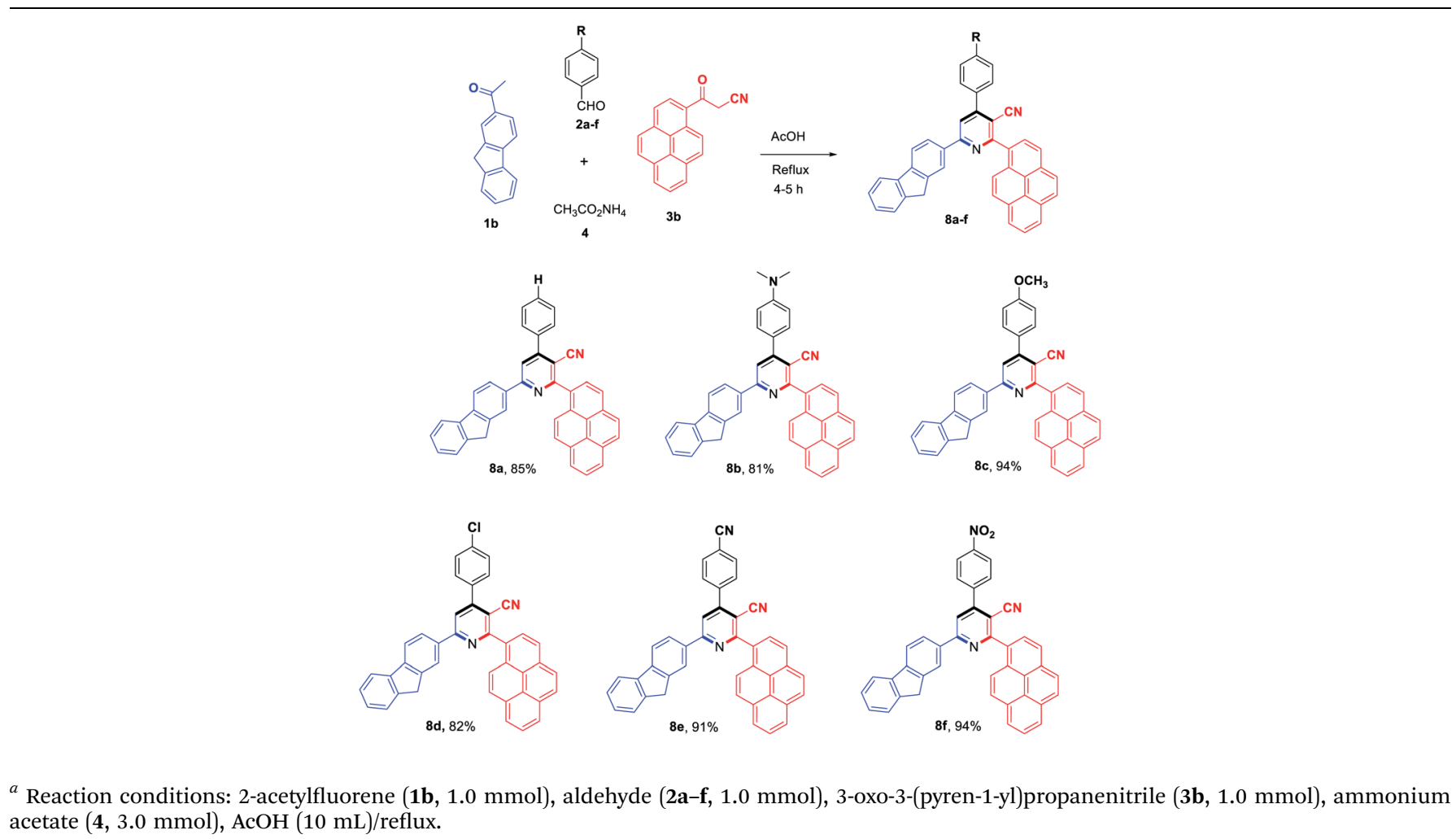

in a quantitative yield, and this was then allowed to react with 1-acetylpyrene (1a) and ammonium acetate (4) to afford the target product $\mathbf{5 a}$.
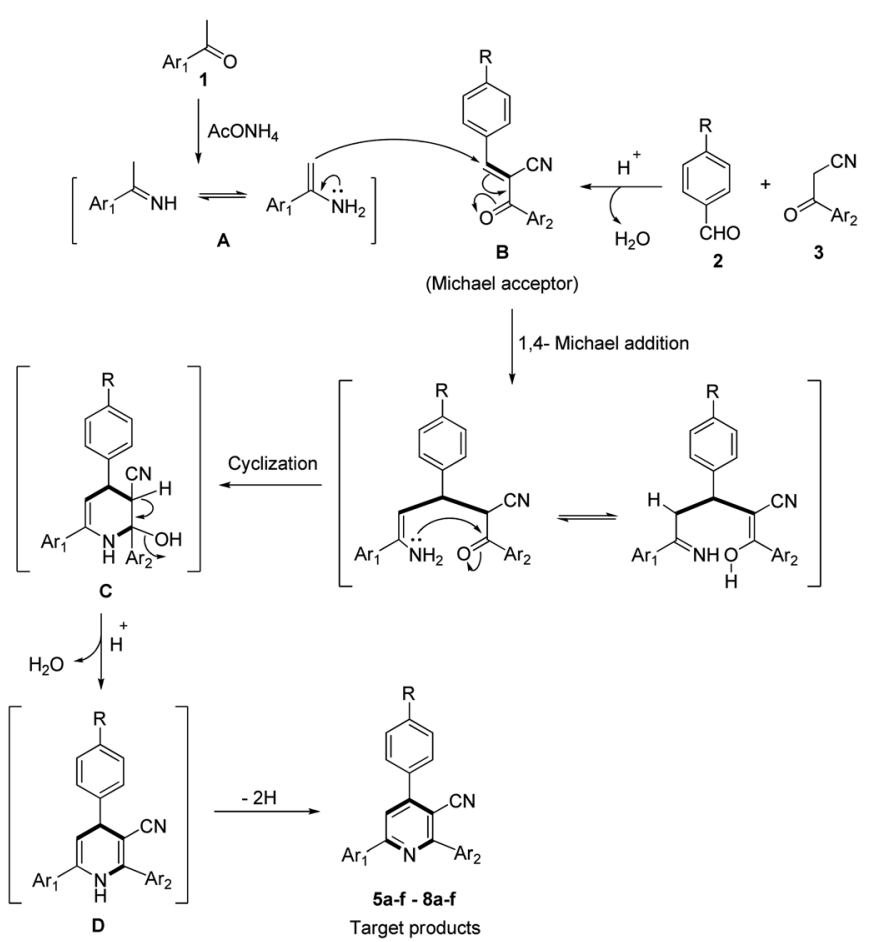

Scheme 3 A plausible mechanism pathway for the synthesized compounds $5 a-f-8 a-f$.

\section{Substituent effect on absorption and emission spectra of the} synthesized nicotinonitrile derivatives $5 a-f-8 a-f$

The UV-visible absorption spectra of the synthesized nicotinonitrile derivatives $\mathbf{5 a - f - 8 a - f}$ were recorded in dichloromethane $\left(\mathrm{CH}_{2} \mathrm{Cl}_{2}\right)$ solution at a concentration of $1 \times 10^{-5} \mathrm{M}$. The UV-visible absorption spectra of the $\mathbf{5 a - f - 8 a - f}$ series in $\mathrm{CH}_{2} \mathrm{Cl}_{2}$ are shown in Fig. 1 and the results are summarized in Table 6 . All of the $\mathbf{5 a - f - 8 a - f}$ compounds exhibited a strong absorption $(\log \varepsilon>4.00)$ (Table 6$)$. The photophysical properties of $7 \mathbf{a}-\mathbf{f}$ with two fluorene fragments in the solution state displayed only one absorption maximum in the range of 313$316 \mathrm{~nm}$ and a substantial shift $(\sim 20 \mathrm{~nm})$ in the absorption band of $\mathbf{7 b}$ corresponding to the $\mathrm{N}\left(\mathrm{CH}_{3}\right)_{2}$ substituent was observed, in which the absorption band appeared at $333 \mathrm{~nm}$ (Fig. 1, system (III)). Moreover, products 5a-f with one fluorene (on $\mathrm{C}_{2}$-position) and the pyrene (on $\mathrm{C}_{6}$-position) fragment of the pyridine moiety showed the absorption maximum with a different energy absorption in the range of $311-370 \mathrm{~nm}$ (Fig. 1, system (I)). However, 6a-f with two pyrene fragments and 8a-f with one pyrene (on $\mathrm{C}_{2}$-position) and fluorene (on $\mathrm{C}_{6}$ position) fragment of pyridine are fairly exceptional in this series, as they showed a conspicuously red shifted absorption band at $448 \mathrm{~nm}$ relative to the electron donating group $\left(-\mathrm{N}\left(\mathrm{CH}_{3}\right)_{2}\right)$ substituent presents on the benzene ring at the $\mathrm{C}_{4}$ position of pyridine (Fig. 1, systems (II) and (IV)). Based on these findings, it can be concluded that owing to the presence of the pyrene fragment on the $\mathrm{C}_{2}$-position of the nicotinonitrile moiety, substantial changes in absorption properties are observed. The broadened band and the pronounced 

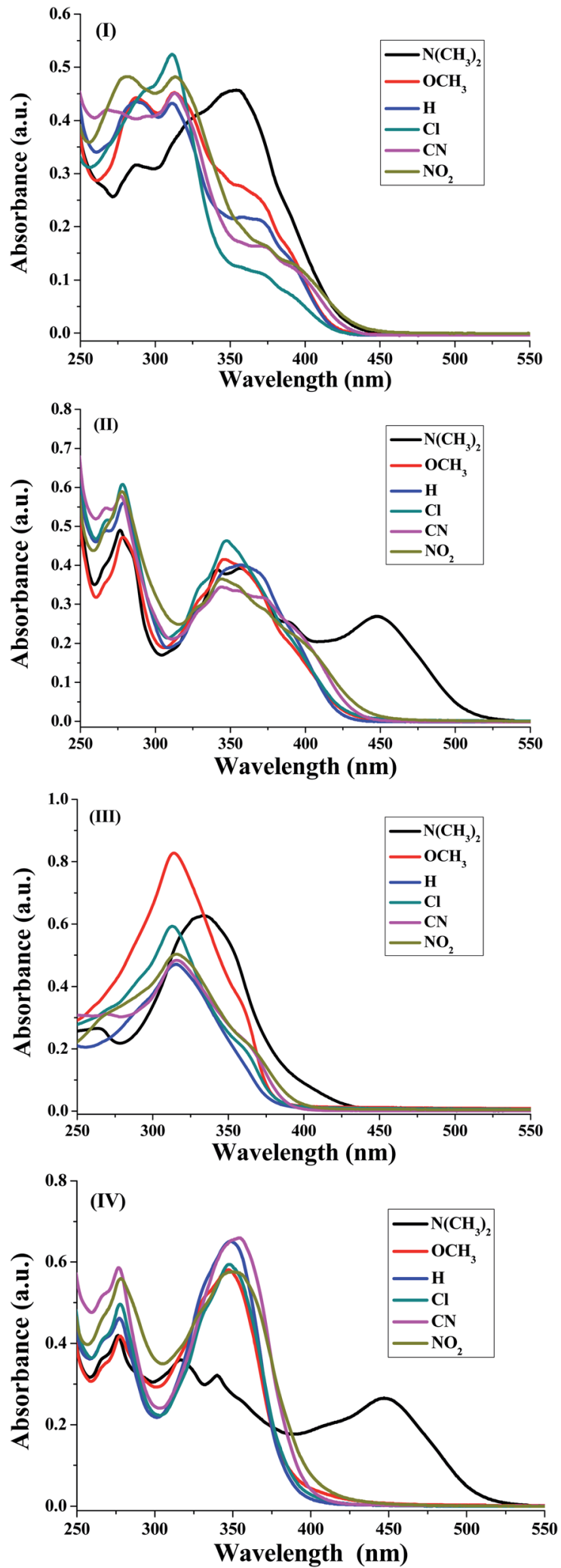

Fig. 1 Absorption spectra of the four synthesized systems (I)-(IV) corresponding to $5 a-f, 6 a-f, 7 a-f$ and $8 a-f$, respectively, in $\mathrm{CH}_{2} \mathrm{Cl}_{2}$ (1 $\left.\times 10^{-5} \mathrm{M}\right)$.
Table 6 The fluorescence and absorption properties of the synthesized compounds $5 a-f-8 a-f$

\begin{tabular}{|c|c|c|c|c|c|c|}
\hline $\mathrm{R}$ & $\lambda_{\mathrm{abs}}(\mathrm{nm})$ & $\log \varepsilon$ & $\lambda_{\mathrm{em}}(\mathrm{nm})$ & $\lambda_{\mathrm{abs}}(\mathrm{nm})$ & $\log \varepsilon$ & $\lambda_{\mathrm{em}}(\mathrm{nm})$ \\
\hline \multirow[t]{3}{*}{ a; $\mathrm{H}$} & 288 & & & 279 & & \\
\hline & 311 & 4.63 & 459 & 357 & 4.60 & 455 \\
\hline & 357 & 4.34 & 585 & & & 593 \\
\hline \multirow[t]{3}{*}{ b; $\mathrm{N}\left(\mathrm{CH}_{3}\right)_{2}$} & 288 & & & 277 & & \\
\hline & 354 & 4.66 & 449 & 356 & 4.59 & 542 \\
\hline & & & 633 & 448 & 4.43 & 590 \\
\hline \multirow[t]{3}{*}{ c; $\mathrm{OCH}_{3}$} & 288 & & & 279 & & \\
\hline & 313 & 4.65 & 449 & 346 & 4.62 & 435 \\
\hline & 359 & 4.44 & 580 & & & 554 \\
\hline \multirow[t]{2}{*}{ d; Cl } & 311 & 4.72 & 469 & 279 & & 474 \\
\hline & 360 & 4.08 & 574 & 348 & 4.66 & 583 \\
\hline \multirow[t]{3}{*}{ e; $\mathrm{CN}$} & 268 & & & 277 & & \\
\hline & 313 & 4.65 & 482 & 345 & 4.53 & 493 \\
\hline & 370 & 4.21 & 618 & & & 616 \\
\hline \multirow[t]{3}{*}{$f ; \mathrm{NO}_{2}$} & 283 & & & 278 & & \\
\hline & 313 & 4.68 & 495 & 345 & 4.56 & 500 \\
\hline & 370 & 4.22 & & & & \\
\hline
\end{tabular}
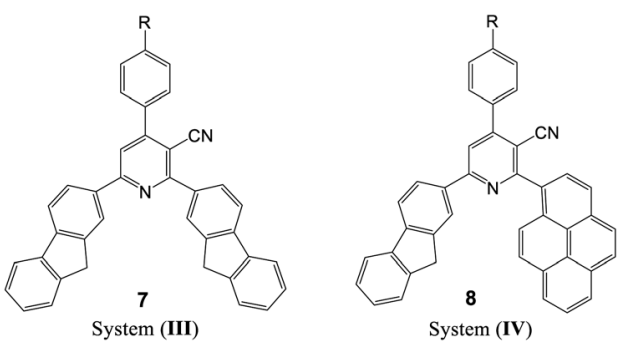

\begin{tabular}{|c|c|c|c|c|c|c|}
\hline $\mathrm{R}$ & $\lambda_{\mathrm{abs}}(\mathrm{nm})$ & $\log \varepsilon$ & $\lambda_{\mathrm{em}}(\mathrm{nm})$ & $\lambda_{\mathrm{abs}}(\mathrm{nm})$ & $\log \varepsilon$ & $\lambda_{\mathrm{em}}(\mathrm{nm})$ \\
\hline \multirow[t]{2}{*}{ a; $\mathrm{H}$} & 316 & 4.67 & 427 & 278 & & 483 \\
\hline & & & 490 & 349 & 4.81 & 544 \\
\hline \multirow[t]{3}{*}{ b; $\mathrm{N}\left(\mathrm{CH}_{3}\right)_{2}$} & 333 & 4.79 & 455 & 277 & & \\
\hline & & & & 340 & 4.50 & 526 \\
\hline & & & 615 & 447 & 4.42 & 584 \\
\hline \multirow[t]{2}{*}{ c; $\mathrm{OCH}_{3}$} & 314 & 4.92 & 412 & 278 & & 475 \\
\hline & & & 505 & 347 & 4.76 & 543 \\
\hline \multirow[t]{2}{*}{ d; Cl } & 313 & 4.77 & 435 & 278 & & \\
\hline & & & 499 & 348 & 4.77 & 513 \\
\hline \multirow[t]{2}{*}{ e; CN } & 316 & 4.68 & 453 & 277 & & \\
\hline & & & 534 & 354 & 4.82 & 548 \\
\hline \multirow[t]{2}{*}{ f; $\mathrm{NO}_{2}$} & 316 & 4.70 & 477 & 279 & & 454 \\
\hline & & & 506 & 350 & 4.76 & 457 \\
\hline
\end{tabular}

bathochromic shift absorption of around $100 \mathrm{~nm}$ can be explained by the transitions having a mixed character of $n-\pi^{*}$ and $\pi-\pi^{*}$. 
The fluorescence emissions of the $\mathbf{5 a}-\mathbf{f}-\mathbf{8 a}-\mathbf{f}$ series with various substituents were recorded in $\mathrm{CH}_{2} \mathrm{Cl}_{2}$ solution at the concentration of $1 \times 10^{-5} \mathrm{M}$ (Fig. 2). The emission spectra are shown in Fig. 3 and the obtained results are summarized in Table 6. In all systems, the fluorescent spectra of the 5a-f-8a-f compounds showed emissions bands at around $450 \pm 30$ and $550 \pm 30 \mathrm{~nm}$ unlike the emissions of $5 \mathbf{e}$ and $6 \mathbf{e}$ (Fig. 2). Amongst them, the nicotinonitrile derivative $5 \mathbf{b}$, which contains a ($\left.\mathrm{N}\left(\mathrm{CH}_{3}\right)_{2}\right)$ group, exhibited the clearest red-shifted emissions bands at 529 and $633 \mathrm{~nm}$. This kind of strong emission is characteristic of compounds containing electron donor and acceptor groups constituting of a conjugated $\pi$-electron system.

In all systems of the $\mathbf{5 a - f - 8 a - f ~ c o m p o u n d s , ~ a ~ l a r g e ~ r e d ~ s h i f t e d ~}$ emission band was detected within the wavelength range 495$633 \mathrm{~nm}$ for compounds 5a-f, 500-616 nm for compounds $\mathbf{6 a - f}$, 490-615 nm for compounds 7a-f and 475-584 nm for 8a-f in addition to the short wavelength band (Table 6). A red shifted broad absorption band indicated that the allowed transition is $\pi-$ $\pi^{*}$ with a charge transfer character. A noteworthy red shift of $100 \mathrm{~nm}$ was observed for nicotinonitriles containing fluorene and pyrene moieties on moving from 7a to $\mathbf{6 a}$, whereas the shift was $50 \mathrm{~nm}$ upon moving from 7a to 8a; suggesting the involvement of a photo induced intramolecular charge transfer (ICT).

It is noticeable that the solutions of most compounds $\mathbf{5 a - f}-$ 8a-f showed a strong fluorescence except for $\mathbf{5 f}, \mathbf{6 f}, \mathbf{7 f}$ and $8 \mathbf{f}$, these compounds present a weak fluorescence in the blue region with maxima in the range of 475-500 $\mathrm{nm}$. This low intensity was initially explained by the existence of $-\mathrm{NO}_{2}$ group. The observed data also corroborates an assumption about the essential role of the cyano group in the pyridine ring causing the high fluorescence of the pyridine derivatives and allows it to act as an excellent fluorescent core with good electron-transporting properties. ${ }^{46-52}$ It can be easily observed from the study that our nicotinonitrile-based fluorescent type molecules containing pyrene and/or fluorene moieties have been proven to be promising fluorophores for application as chemo- and biosensors. Moreover, this type of structure with a highly electron deficient system could be of interest to many researchers working on the development of n-type organic semiconductors and for the design of new liquid crystal materials.

\section{Conclusions}

In conclusion, we have developed a simple and efficient protocol for the synthesis of a novel series of pyrene and/or
(I)

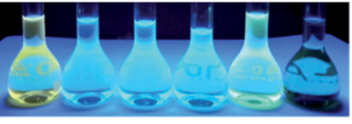

(II)

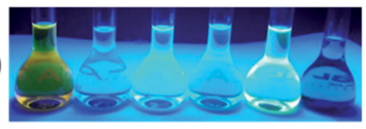

(III)

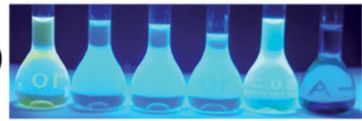

(iv)

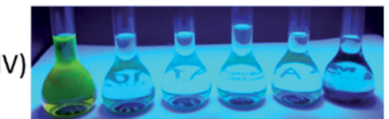

Fig. 2 Effects of the substituents on the fluorescence emission of (I)(IV) in $\mathrm{CH}_{2} \mathrm{Cl}_{2}$ solution (substituents from left to right are: $\mathrm{N}\left(\mathrm{CH}_{3}\right)_{2}$, $\mathrm{OCH}_{3}, \mathrm{H}, \mathrm{Cl}$, and $\mathrm{CN}, \mathrm{NO}_{2}$ ).
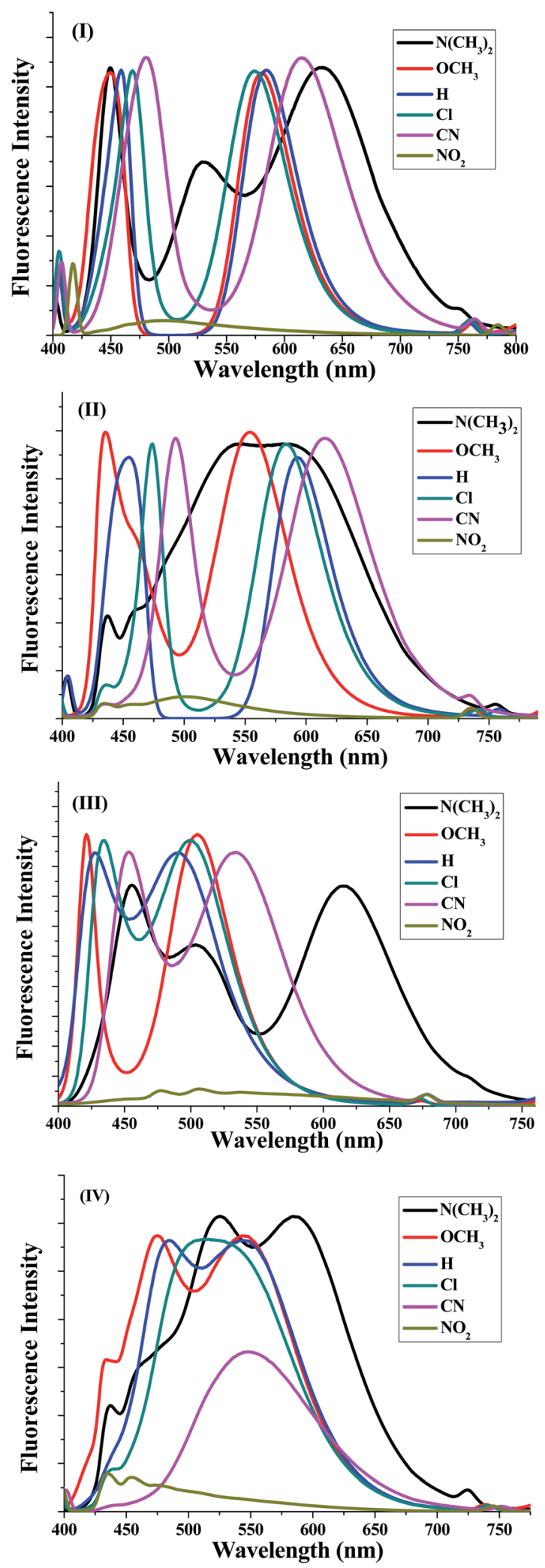

Fig. 3 Fluorescence spectra of the four synthesized systems (I)-(IV) corresponding to $5 a-f, 6 a-f, 7 a-f$ and $8 a-f$, respectively, in dichloromethane $\left(1 \times 10^{-5} \mathrm{M}\right)$. 
fluorene-containing nicotinonitrile derivatives bearing electrondonating and electro-withdrawing groups via one-pot fourcomponent condensation reactions of 1-(pyren-1-yl)ethanone/ 1-(9H-fluoren-2-yl)ethanone, different aromatic aldehydes, 3oxo-3-(pyren-1-yl)propanenitrile/3-(9H-fluoren-2-yl)-3-

oxopropanenitrile, and ammonium acetate in acetic acid as a reaction media under reflux conditions. This procedure offers several distinguished advantages, such as, a relatively short reaction time, excellent yields, and easy reaction work up (with no need for chromatographic separation). The photophysical properties of the synthesized nicotinonitriles were investigated using UV-visible absorption and fluorescence emission spectrophotometers, using $\mathrm{CH}_{2} \mathrm{Cl}_{2}$ as the solvent, and significant results were obtained. Moreover, the optical results revealed that the $\lambda_{\text {abs }}$ values are in the range of 311-447 $\mathrm{nm}$ (solution state) while the $\lambda_{\mathrm{em}}$ values are in the range of 421-493 and 543$633 \mathrm{~nm}$. The absorption and emission at long wavelengths are a result of an increase in the push-pull system generated by the two pyrene/fluorene rings and the cyano $(\mathrm{C} \equiv \mathrm{N})$ group attached to the pyridine ring. More details relating to fluorescence emission, time-resolved spectroscopy, solvatochromism and theoretical studies of these newly synthesized materials will be discussed in depth in a forthcoming paper.

\section{Experimental}

\section{Materials and methods}

All solvents used purchased from Sigma-Aldrich were of spectroscopic grade and were used without further purification. The FT-IR spectra were recorded on a Shimadzu IR-3600 FT-IR spectrometer in $\mathrm{KBr}$ pellets. The NMR spectra were acquired on a Bruker Avance 500 instrument (at $500 \mathrm{MHz}$ for ${ }^{1} \mathrm{H}, 125$ $\mathrm{MHz}$ for ${ }^{13} \mathrm{C}$ ) in $\mathrm{CDCl}_{3}$ solutions, using residual solvent signals as the internal standards. Melting points were determined on a Stuart SMP3 melting point apparatus and are uncorrected. The electronic absorption spectra were recorded using a UV/VIS/ NIR spectrophotometer in a concentration of $1 \times 10^{-5} \mathrm{~mol}$ $\mathrm{dm}^{-3}$. Fluorescence spectra were performed using a Horiba Spectrofluorometer (model FluoroMax-4).

1-Acetylpyrene (1a) and 2-acetyl-9H-fluorene (1b) were synthesized from pyrene and fluorene, respectively, using the classical Friedel-Crafts reaction in accordance with the previously reported procedure. ${ }^{53,54} 3$-(9H-Fluoren-2-yl)-3oxopropanenitrile (3a) and 3-oxo-3-(pyren-1-yl)propanenitrile (3b) were synthesized from 1-acetylpyrene and 2-acetyl-9H-fluorene, respectively, according to the previously reported procedures. $^{55,56}$

\section{Synthetic procedures}

General procedure for the synthesis of pyrene and/or fluorene-containing nicotinonitrile derivatives $\mathbf{5 a - f - 8 a - f . ~ I n ~}$ a $50 \mathrm{~mL}$ round-bottomed flask, a mixture of acetyl compound 1 (1.0 mmol), aldehyde $2(1.0 \mathrm{mmol})$, nitrile compound 3 (1.0 $\mathrm{mmol})$, and ammonium acetate $(4,3.0 \mathrm{mmol})$ in acetic acid (10 $\mathrm{mL}$ ) was heated under reflux for the appropriate time, as mentioned in Tables 2-5. After the completion of the reaction (as monitored by TLC), the resulting product was filtered off, washed with water $(3 \times 10 \mathrm{~mL})$, and dried under vacuum. The product obtained was essentially pure in all cases.

2-(9H-Fluoren-2-yl)-4-phenyl-6-(pyren-1-yl)nicotinonitrile

(5a). Yellow crystals; yield (94\%), mp 250-252 ${ }^{\circ} \mathrm{C}$. FT-IR (KBr): $\nu_{\max }=3050$ (CH arom.), $2210(\mathrm{CN}), 1613(\mathrm{C}=\mathrm{N}) \mathrm{cm}^{-1} \cdot{ }^{1} \mathrm{H} \mathrm{NMR}$ $\left(\mathrm{CDCl}_{3}\right): \delta=8.58(\mathrm{~d}, J=6.5 \mathrm{~Hz}, 1 \mathrm{H}), 8.34-8.32(\mathrm{~m}, 2 \mathrm{H}), 8.28-$ 8.26 (m, 2H), 8.20-8.16 (m, 3H), 8.10-8.08 (m, 1H), 8.00 (s, 1H), $7.89-7.83(\mathrm{~m}, 4 \mathrm{H}), 7.67-7.61(\mathrm{~m}, 4 \mathrm{H}), 7.52(\mathrm{~d}, J=11.5 \mathrm{~Hz}, 1 \mathrm{H})$, 7.44-7.38 (m, 3H), 4.00 (d, $\left.{ }^{2} J=35.5 \mathrm{~Hz}, 2 \mathrm{H}, \mathrm{CH}_{2}\right) \mathrm{ppm} .{ }^{13} \mathrm{C} \mathrm{NMR}$ $\left(\mathrm{CDCl}_{3}\right): \delta=162.9(\mathrm{C}=\mathrm{N}), 161.8(\mathrm{C}), 155.1(\mathrm{C}), 145.0(\mathrm{C}), 144.1$ (C), 144.0 (C), 143.7 (C), 143.5 (C), 140.9 (C), 136.5 (C), 136.0 (C), 133.8 (C), $132.3(\mathrm{C}), 130.1(\mathrm{CH}), 129.1(\mathrm{CH}), 128.8(\mathrm{CH}), 128.7$ $(\mathrm{CH}), 128.6(\mathrm{CH}), 128.5(\mathrm{CH}), 128.0(\mathrm{CH}), 127.8(\mathrm{CH}), 127.7(\mathrm{CH})$, $127.4(\mathrm{CH}), 127.3(\mathrm{CH}), 126.9(\mathrm{CH}), 126.3(\mathrm{CH}), 126.2(\mathrm{CH}), 125.9$ $(\mathrm{CH}), 125.5(\mathrm{CH}), 125.1(\mathrm{CH}), 124.9(\mathrm{CH}), 124.2(\mathrm{CH}), 124.0(\mathrm{CH})$, $120.5(\mathrm{CH}), 119.9(\mathrm{CH}), 117.9(\mathrm{C}), 104.2(\mathrm{CN}), 36.9\left(\mathrm{CH}_{2}\right) \mathrm{ppm}$. Elemental analysis: calcd for $\mathrm{C}_{41} \mathrm{H}_{24} \mathrm{~N}_{2}$ : C, 90.42; H, 4.44; N, 5.14; found: C, 90.19; H, 4.25; N, 4.90 .

4-(4-(Dimethylamino)phenyl)-2-(9H-fluoren-2-yl)-6-(pyren-1yl)nicotinonitrile (5b). Yellow crystals; yield (86\%), mp 170$172{ }^{\circ} \mathrm{C}$. FT-IR (KBr): $\nu_{\max }=3049$ (CH arom.), 2946 (CH aliph.), $2200(\mathrm{CN}), 1615(\mathrm{C}=\mathrm{N}) \mathrm{cm}^{-1} \cdot{ }^{1} \mathrm{H}$ NMR $\left(\mathrm{CDCl}_{3}\right): \delta=8.59(\mathrm{~d}, J=$ $8.0 \mathrm{~Hz}, 1 \mathrm{H}), 8.40$ (d, $J=5.5 \mathrm{~Hz}, 1 \mathrm{H}), 8.35-8.30$ (m, 5H), 8.18-8.16 $(\mathrm{m}, 4 \mathrm{H}), 8.08(\mathrm{~d}, J=6.0 \mathrm{~Hz}, 2 \mathrm{H}), 7.97(\mathrm{~s}, 1 \mathrm{H}), 7.88-7.85(\mathrm{~m}, 2 \mathrm{H})$, $7.78(\mathrm{~d}, J=6.5 \mathrm{~Hz}, 1 \mathrm{H}), 7.61-7.59(\mathrm{~m}, 1 \mathrm{H}), 7.42-7.38(\mathrm{~m}, 3 \mathrm{H})$, $3.98\left(\mathrm{~d},{ }^{2} \mathrm{~J}=35.5 \mathrm{~Hz}, 2 \mathrm{H}, \mathrm{CH}_{2}\right), 3.08\left(\mathrm{~s}, 3 \mathrm{H}, \mathrm{CH}_{3}\right), 2.92(\mathrm{~s}, 3 \mathrm{H}$, $\left.\mathrm{CH}_{3}\right)$ ppm. ${ }^{13} \mathrm{C} \mathrm{NMR}\left(\mathrm{CDCl}_{3}\right): \delta=163.2(\mathrm{C}=\mathrm{N}), 162.4(\mathrm{C}), 147.8$ (C), 145.2 (C), 144.2 (C), 144.0 (C), 143.8 (C), 143.4 (C), 141.1 (C), 140.5 (C), 134.2 (C), 134.0 (C), 131.9 (C), 131.3 (C), 131.0 (C), 130.8 (C), 130.5 (C), $130.1(\mathrm{CH}), 129.7(\mathrm{CH}), 129.6(\mathrm{CH}), 129.5$ $(\mathrm{CH}), 128.4(\mathrm{CH}), 128.0(\mathrm{CH}), 127.2(\mathrm{CH}), 127.1(\mathrm{CH}), 126.4(\mathrm{CH})$, $126.3(\mathrm{CH}), 126.2(\mathrm{CH}), 126.1(\mathrm{CH}), 125.9(\mathrm{CH}), 125.2(\mathrm{CH}), 124.9$ $(\mathrm{CH}), 124.0(\mathrm{CH}), 123.2(\mathrm{CH}), 120.8(\mathrm{CH}), 120.5(\mathrm{CH}), 120.2(\mathrm{CH})$, $119.8(\mathrm{CH}), 116.6(\mathrm{C}), 104.4(\mathrm{CN}), 37.0\left(\mathrm{CH}_{2}\right), 30.5\left(\mathrm{CH}_{3}\right) \mathrm{ppm}$. Elemental analysis: calcd for $\mathrm{C}_{43} \mathrm{H}_{29} \mathrm{~N}_{3}$ : C, 87.88; $\mathrm{H}, 4.97 ; \mathrm{N}$, 7.15; found: C, 87.65; $\mathrm{H}, 4.81 ; \mathrm{N}, 6.88$.

2-(9H-Fluoren-2-yl)-4-(4-methoxyphenyl)-6-(pyren-1-yl) nicotinonitrile (5c). Yellow crystals; yield (89\%), $\mathrm{mp} 221-223^{\circ} \mathrm{C}$. FT-IR (KBr): $\nu_{\max }=3050$ (CH arom.), $2206(\mathrm{CN}), 1615(\mathrm{C}=$ N) $\mathrm{cm}^{-1} \cdot{ }^{1} \mathrm{H} \mathrm{NMR}\left(\mathrm{CDCl}_{3}\right): \delta=8.44(\mathrm{~s}, 1 \mathrm{H}), 8.40(\mathrm{~d}, J=14.0 \mathrm{~Hz}$, $2 \mathrm{H})$, 8.24-8.18 (m, 5H), 8.10-8.04 (m, 3H), 7.90-7.82 (m, 4H), 7.64-7.58 (m, 1H), 7.43-7.38 (m, 3H), 7.15-7.13 (m, 2H), 3.97 (d, $\left.{ }^{2} J=21.5 \mathrm{~Hz}, 2 \mathrm{H}, \mathrm{CH}_{2}\right), 3.93\left(\mathrm{~s}, 3 \mathrm{H}, \mathrm{CH}_{3}\right) \mathrm{ppm} .{ }^{13} \mathrm{C} \mathrm{NMR}\left(\mathrm{CDCl}_{3}\right)$ : $\delta=163.6(\mathrm{C}=\mathrm{N}), 161.2(\mathrm{C}), 159.1(\mathrm{C}), 154.5(\mathrm{C}), 144.2(\mathrm{C}), 144.1$ (C), 144.0 (C), 140.8 (C), 132.4 (C), 131.3 (C), 130.3 (CH), 129.4 $(\mathrm{CH}), 128.5(\mathrm{CH}), 128.4(\mathrm{CH}), 127.5(\mathrm{CH}), 127.4(\mathrm{CH}), 127.0(\mathrm{CH})$, $126.7(\mathrm{CH}), 126.2(\mathrm{CH}), 125.7(\mathrm{CH}), 125.5(\mathrm{CH}), 125.2(\mathrm{CH}), 124.6$ $(\mathrm{CH}), 124.4(\mathrm{CH}), 120.5(\mathrm{CH}), 120.2(\mathrm{CH}), 114.6(\mathrm{CH}), 107.0(\mathrm{CN})$, $55.5\left(\mathrm{CH}_{3}\right), 37.0\left(\mathrm{CH}_{2}\right)$ ppm. Elemental analysis: calcd for $\mathrm{C}_{42} \mathrm{H}_{26} \mathrm{~N}_{2} \mathrm{O}$ : C, 87.78; H, 4.56; N, 4.87; found: C, 87.60; $\mathrm{H}$, $4.45 ; \mathrm{N}, 4.69$.

4-(4-Chlorophenyl)-2-(9H-fluoren-2-yl)-6-(pyren-1-yl) nicotinonitrile (5d). Yellow crystals; yield (90\%), mp 291$292{ }^{\circ} \mathrm{C}$. FT-IR (KBr): $\nu_{\max }=3050$ (CH arom.), 2199 (CN), 1611 $(\mathrm{C}=\mathrm{N}) \mathrm{cm}^{-1} \cdot{ }^{1} \mathrm{H}$ NMR $\left(\mathrm{CDCl}_{3}\right): \delta=8.56(\mathrm{~s}, 1 \mathrm{H}), 8.32(\mathrm{~s}, 1 \mathrm{H})$, 8.28-8.26 (m, 3H), 8.20-8.16 (m, 3H), 8.10-8.08 (m, 1H), 8.00 (s, 
1H), 7.90-7.82 (m, 3H), 7.76-7.74 (m, 2H), 7.64-7.60 (m, 3H), 7.48-7.39 (m, 3H), 4.01 (d, $\left.{ }^{2} \mathrm{~J}=32.0 \mathrm{~Hz}, 2 \mathrm{H}, \mathrm{CH}_{2}\right) \mathrm{ppm} .{ }^{13} \mathrm{C} \mathrm{NMR}$ $\left(\mathrm{CDCl}_{3}\right): \delta=162.9(\mathrm{C}=\mathrm{N}), 162.1(\mathrm{C}), 153.9(\mathrm{C}), 144.2(\mathrm{C}), 144.0$ (C), 143.9 (C), 143.7 (C), 143.6 (C), 140.9 (C), 140.2 (C), 136.5 (C), 135.8 (C), 134.9 (C), 133.6 (C), 132.3 (C), 131.3 (C), 130.7 (C), $130.2(\mathrm{CH}), 129.6(\mathrm{CH}), 129.4(\mathrm{CH}), 129.1(\mathrm{CH}), 128.8(\mathrm{CH}), 128.7$ $(\mathrm{CH}), 127.5(\mathrm{CH}), 127.3(\mathrm{CH}), 127.1(\mathrm{CH}), 126.9(\mathrm{CH}), 126.3(\mathrm{CH})$, $126.2(\mathrm{CH}), 125.9(\mathrm{CH}), 125.6(\mathrm{CH}), 125.1(\mathrm{CH}), 124.9(\mathrm{CH}), 124.2$ $(\mathrm{CH}), 120.5(\mathrm{CH}), 119.9(\mathrm{CH}), 117.7(\mathrm{C}), 104.0(\mathrm{CN}), 37.1$ $\left(\mathrm{CH}_{2}\right)$ ppm. Elemental analysis: calcd for $\mathrm{C}_{41} \mathrm{H}_{23} \mathrm{ClN}_{2}$ : C, 85.04; $\mathrm{H}, 4.00 ; \mathrm{N}, 4.84$; Cl, 6.12; found: C, 84.76; H, 3.79; N, 4.68; Cl, 5.90 .

4-(4-Cyanophenyl)-2-(9H-fluoren-2-yl)-6-(pyren-1-yl)

nicotinonitrile (5e). Yellow crystals; yield (95\%), $\mathrm{mp}>310{ }^{\circ} \mathrm{C}$. FT-IR (KBr): $\nu_{\max }=3046$ (CH arom.), 2218, 2217 (CN), $1611(\mathrm{C}=$ N) $\mathrm{cm}^{-1} \cdot{ }^{1} \mathrm{H} \mathrm{NMR}\left(\mathrm{CDCl}_{3}\right): \delta=8.45(\mathrm{~d}, J=7.5 \mathrm{~Hz}, 1 \mathrm{H}), 8.21(\mathrm{~s}$, $1 \mathrm{H}), 8.18-8.16(\mathrm{~m}, 3 \mathrm{H}), 8.10-8.05(\mathrm{~m}, 3 \mathrm{H}), 8.00-7.98(\mathrm{~m}, 1 \mathrm{H})$, 7.90-7.88 (m, 1H), 7.79-7.73 (m, 6H), 7.54-7.50 (m, 2H), 7.34$7.31(\mathrm{~m}, 2 \mathrm{H}), 7.18$ (s, 1H), $3.91\left(\mathrm{~d},{ }^{2} J=30.5 \mathrm{~Hz}, 2 \mathrm{H}, \mathrm{CH}_{2}\right) \mathrm{ppm}$. ${ }^{13} \mathrm{C} \mathrm{NMR}\left(\mathrm{CDCl}_{3}\right): \delta=163.0(\mathrm{C}=\mathrm{N}), 162.5(\mathrm{C}), 152.9(\mathrm{C}), 144.0$ (C), 143.6 (C), 140.9 (C), 140.8 (C), 135.7 (C), 133.4 (C), 133.2 (C), $132.8(\mathrm{CH}), 132.4(\mathrm{C}), 131.3(\mathrm{C}), 130.7(\mathrm{C}), 129.6(\mathrm{CH}), 128.9$ $(\mathrm{CH}), 128.8(\mathrm{CH}), 128.5(\mathrm{CH}), 127.7(\mathrm{CH}), 127.6(\mathrm{CH}), 127.3(\mathrm{CH})$, $127.0(\mathrm{CH}), 126.4(\mathrm{CH}), 126.2(\mathrm{CH}), 126.1(\mathrm{CH}), 125.6(\mathrm{CH}), 125.2$ $(\mathrm{CH}), 124.9(\mathrm{CH}), 124.6(\mathrm{C}), 124.0(\mathrm{CH}), 123.4(\mathrm{CH}), 120.6(\mathrm{CH})$, 120.0 (CH), 118.1 (C), 117.4 (C), 113.9 (C), 103.6 (CN), 37.0 $\left(\mathrm{CH}_{2}\right)$ ppm. Elemental analysis: calcd for $\mathrm{C}_{42} \mathrm{H}_{23} \mathrm{~N}_{3}: \mathrm{C}, 88.55 ; \mathrm{H}$, 4.07; N, 7.38; found: C, 88.30; H, 3.92; N, 7.10.

2-(9H-Fluoren-2-yl)-4-(4-nitrophenyl)-6-(pyren-1-yl)

nicotinonitrile (5f). Pale brown crystals; yield (97\%), mp 285$287{ }^{\circ} \mathrm{C}$. FT-IR (KBr): $\nu_{\max }=3044$ (CH arom.), $2209(\mathrm{CN}), 1615$ $(\mathrm{C}=\mathrm{N}) \mathrm{cm}^{-1} \cdot{ }^{1} \mathrm{H}$ NMR $\left(\mathrm{CDCl}_{3}\right): \delta=8.56(\mathrm{~d}, J=6.5 \mathrm{~Hz}, 1 \mathrm{H}), 8.45$ $(\mathrm{s}, 1 \mathrm{H}), 8.37-8.33(\mathrm{~m}, 3 \mathrm{H}), 8.27-8.16(\mathrm{~m}, 4 \mathrm{H}), 8.10-8.08(\mathrm{~m}, 1 \mathrm{H})$, 8.00-7.95 (m, 2H), 7.89-7.86 (m, 2H), $7.81(\mathrm{~s}, 1 \mathrm{H}), 7.72-7.70(\mathrm{~m}$, 1H), 7.64-7.60 (m, 2H), 7.44-7.40 (m, 3H), $4.01\left(\mathrm{~d},{ }^{2} J=33.0 \mathrm{~Hz}\right.$, $\left.2 \mathrm{H}, \mathrm{CH}_{2}\right)$ ppm. ${ }^{13} \mathrm{C} \mathrm{NMR}\left(\mathrm{CDCl}_{3}\right): \delta=163.0(\mathrm{C}=\mathrm{N}), 162.4(\mathrm{C})$, 152.5 (C), 148.7 (C), 148.6 (C), 147.8 (C), 145.4 (C), 144.2 (C), 142.7 (C), 140.8 (C), 139.7 (C), 135.6 (C), 132.3 (C), 131.2 (C), $130.7(\mathrm{C}), 130.0(\mathrm{CH}), 129.0(\mathrm{CH}), 128.8(\mathrm{CH}), 128.7(\mathrm{CH}), 127.3$ $(\mathrm{CH}), 127.2(\mathrm{CH}), 127.0(\mathrm{CH}), 126.4(\mathrm{CH}), 126.3(\mathrm{CH}), 125.6(\mathrm{CH})$, 125.3 (CH), 125.2 (CH), 124.9 (CH), 124.7 (CH), $124.2(\mathrm{CH}), 123.4$ $(\mathrm{CH}), 120.7(\mathrm{CH}), 120.0(\mathrm{CH}), 118.6(\mathrm{C}), 107.2(\mathrm{CN}), 37.1$ $\left(\mathrm{CH}_{2}\right)$ ppm. Elemental analysis: calcd for $\mathrm{C}_{41} \mathrm{H}_{23} \mathrm{~N}_{3} \mathrm{O}_{2}$ : C, 83.52; H, 3.93; N, 7.13; found: C, 83.33; H, 3.69; N, 7.00.

4-Phenyl-2,6-di(pyren-1-yl)nicotinonitrile (6a). Yellow crystals; yield (88\%), mp 269-270 ${ }^{\circ} \mathrm{C}$. FT-IR (KBr): $\nu_{\max }=3041(\mathrm{CH}$ arom.), $2198(\mathrm{CN}), 1612(\mathrm{C}=\mathrm{N}) \mathrm{cm}^{-1} \cdot{ }^{1} \mathrm{H} \mathrm{NMR}\left(\mathrm{CDCl}_{3}\right): \delta=8.59$ $(\mathrm{d}, J=7.5 \mathrm{~Hz}, 1 \mathrm{H}), 8.28-8.25(\mathrm{~m}, 3 \mathrm{H}), 8.18(\mathrm{~d}, J=6.5 \mathrm{~Hz}, 2 \mathrm{H})$, 8.14-8.11 (m, 4H), 8.07-8.01 (m, 5H), 7.96-7.94 (m, 3H), 7.78 (d, $J=6.5 \mathrm{~Hz}, 2 \mathrm{H}), 7.52-7.49(\mathrm{~m}, 3 \mathrm{H}), 7.16-7.14(\mathrm{~m}, 1 \mathrm{H}) \mathrm{ppm} .{ }^{13} \mathrm{C}$ NMR $\left(\mathrm{CDCl}_{3}\right): \delta=164.0(\mathrm{C}=\mathrm{N}), 161.9(\mathrm{C}), 154.1(\mathrm{C}), 136.3(\mathrm{C})$, $131.3(\mathrm{C}), 130.2(\mathrm{CH}), 129.2(\mathrm{CH}), 129.0(\mathrm{CH}), 128.9(\mathrm{CH}), 128.8$ (C), $128.7(\mathrm{CH}), 128.6(\mathrm{CH}), 128.5(\mathrm{CH}), 128.0(\mathrm{CH}), 127.6(\mathrm{CH})$, $127.4(\mathrm{CH}), 127.3(\mathrm{CH}), 126.3(\mathrm{CH}), 126.2(\mathrm{CH}), 125.9(\mathrm{CH}), 125.8$ $(\mathrm{CH}), 125.6(\mathrm{CH}), 125.5(\mathrm{CH}), 124.9(\mathrm{CH}), 124.7(\mathrm{CH}), 124.4(\mathrm{CH})$, $124.3(\mathrm{CH}), 124.2(\mathrm{CH}), 117.1(\mathrm{C}), 107.5(\mathrm{CN})$ ppm. Elemental analysis: calcd for $\mathrm{C}_{44} \mathrm{H}_{24} \mathrm{~N}_{2}$ : C, 91.01; H, 4.17; N, 4.82; found: $\mathrm{C}$, 90.80; H, 4.00; N, 4.69.

\section{4-(4-(Dimethylamino)phenyl)-2,6-di(pyren-1-yl)}

nicotinonitrile (6b). Red crystals; yield (83\%), mp 132-135 ${ }^{\circ} \mathrm{C}$. FT-IR (KBr): $\nu_{\max }=3049$ (CH arom.), $2210(\mathrm{CN}), 1615(\mathrm{C}=$ $\mathrm{N}) \mathrm{cm}^{-1} \cdot{ }^{1} \mathrm{H}$ NMR $\left(\mathrm{CDCl}_{3}\right): \delta=9.07(\mathrm{~d}, J=8.5 \mathrm{~Hz}, 1 \mathrm{H}), 8.38-8.34$ $(\mathrm{m}, 2 \mathrm{H}), 8.28-8.22(\mathrm{~m}, 6 \mathrm{H}), 8.16-8.12(\mathrm{~m}, 5 \mathrm{H}), 8.10-8.05(\mathrm{~m}$, $5 \mathrm{H}), 7.89$ (d, J=6.5 Hz, 2H, Ph-H), 6.61 (d, $J=6.5 \mathrm{~Hz}, 2 \mathrm{H}, \mathrm{Ph}-\mathrm{H})$, $3.05\left(\mathrm{~s}, 3 \mathrm{H}, \mathrm{CH}_{3}\right), 2.91\left(\mathrm{~s}, 3 \mathrm{H}, \mathrm{CH}_{3}\right) \mathrm{ppm} .{ }^{13} \mathrm{C} \mathrm{NMR}\left(\mathrm{CDCl}_{3}\right): \delta=$ $164.6(\mathrm{C}=\mathrm{N}), 156.1$ (C), 153.9 (C), 134.7 (C), 134.0 (C), 130.0 (C), 132.3 (C) 131.8 (C), 131.1 (C), 131.0 (C), 130.6 (C), $130.4(\mathrm{CH})$, $129.7(\mathrm{CH}), 129.6(\mathrm{CH}), 129.4(\mathrm{CH}), 129.2(\mathrm{CH}), 129.1(\mathrm{CH}), 129.0$ $(\mathrm{CH}), 127.2(\mathrm{CH}), 127.1(\mathrm{CH}), 127.0(\mathrm{CH}), 126.4(\mathrm{CH}), 126.3(\mathrm{CH})$, $126.1(\mathrm{CH}), 125.9(\mathrm{CH}), 125.7(\mathrm{CH}), 124.9(\mathrm{CH}), 124.7(\mathrm{CH}), 124.3$ $(\mathrm{CH}), 124.0(\mathrm{CH}), 119.4(\mathrm{CH}), 118.6(\mathrm{C}), 111.6(\mathrm{CH}), 104.3(\mathrm{CN})$, $40.0\left(\mathrm{CH}_{3}\right)$ ppm. Elemental analysis: calcd for $\mathrm{C}_{46} \mathrm{H}_{29} \mathrm{~N}_{3}$ : C, 88.58; H, 4.69; N, 6.74; found: C, 88.34; H, 4.40; N, 6.60.

4-(4-Methoxyphenyl)-2,6-di(pyren-1-yl)nicotinonitrile

(6c). Red crystals; yield (75\%), mp 219-220 ${ }^{\circ} \mathrm{C}$. FT-IR (KBr): $\nu_{\max }=$ 3036 (CH arom.), $2215(\mathrm{CN}), 1612(\mathrm{C}=\mathrm{N}) \mathrm{cm}^{-1} \cdot{ }^{1} \mathrm{H}$ NMR $\left(\mathrm{CDCl}_{3}\right): \delta=8.69(\mathrm{~d}, J=9.5 \mathrm{~Hz}, 1 \mathrm{H}), 8.65(\mathrm{~d}, J=8.0 \mathrm{~Hz}, 1 \mathrm{H}), 8.39$ $(\mathrm{s}, 1 \mathrm{H}), 8.37-8.31(\mathrm{~m}, 2 \mathrm{H}), 8.28-8.05(\mathrm{~m}, 14 \mathrm{H}), 7.87(\mathrm{~d}, J=$ $8.0 \mathrm{~Hz}, 2 \mathrm{H}, \mathrm{Ph}-\mathrm{H}$ ), 7.13 (d, $J=8.0 \mathrm{~Hz}, 2 \mathrm{H}, \mathrm{Ph}-\mathrm{H}), 3.89$ (s, 3H, $\left.\mathrm{CH}_{3}\right)$ ppm. ${ }^{13} \mathrm{C} \mathrm{NMR}\left(\mathrm{CDCl}_{3}\right): \delta=164.1(\mathrm{C}=\mathrm{N}), 161.8(\mathrm{C}), 153.7$ (C), 133.8 (C), 132.9 (C), 132.3 (C), 132.2 (C), 131.8 (C) 131.4 (C), 131.3 (C), 130.9 (C), 130.8 (C), 130.7 (C), 130.6 (C), 130.5 (C), $130.4(\mathrm{CH}), 128.7(\mathrm{CH}), 128.6(\mathrm{CH}), 128.3(\mathrm{CH}), 128.1(\mathrm{CH}), 127.5$ $(\mathrm{CH}), 127.4(\mathrm{CH}), 127.3(\mathrm{CH}), 126.3(\mathrm{CH}), 126.2(\mathrm{CH}), 126.1(\mathrm{CH})$, 125.6 (CH), 125.5 (CH), 125.2 (CH), $124.9(\mathrm{CH}), 124.8(\mathrm{CH}), 124.7$ $(\mathrm{CH}), 117.4(\mathrm{C}), 114.8(\mathrm{CH}), 114.6(\mathrm{CH}), 114.4(\mathrm{CH}), 114.3(\mathrm{CH})$, $107.2(\mathrm{CN}), 55.5\left(\mathrm{CH}_{3}\right)$ ppm. Elemental analysis: calcd for $\mathrm{C}_{45} \mathrm{H}_{26} \mathrm{~N}_{2} \mathrm{O}$ : C, 88.50; H, 4.29; N, 4.59; found: C, 88.22; H, $4.31 ; \mathrm{N}, 4.37$.

4-(4-Chlorophenyl)-2,6-di(pyren-1-yl)nicotinonitrile (6d). Pale brown crystals; yield (86\%), mp 289-290 ${ }^{\circ} \mathrm{C}$. FT-IR (KBr): $\nu_{\max }=3040$ (CH arom.), $2210(\mathrm{CN}), 1615(\mathrm{C}=\mathrm{N}) \mathrm{cm}^{-1} \cdot{ }^{1} \mathrm{H} \mathrm{NMR}$ $\left(\mathrm{CDCl}_{3}\right): \delta=8.67(\mathrm{~s}, 1 \mathrm{H}), 8.41-8.37(\mathrm{~m}, 3 \mathrm{H}), 8.32(\mathrm{~m}, 1 \mathrm{H}), 8.27-$ $8.24(\mathrm{~m}, 6 \mathrm{H}), 8.18-8.14(\mathrm{~m}, 4 \mathrm{H}), 8.08-8.05(\mathrm{~m}, 4 \mathrm{H}), 7.84(\mathrm{~d}, J=$ $7.5 \mathrm{~Hz}, 2 \mathrm{H}), 7.62(\mathrm{~d}, J=7.5 \mathrm{~Hz}, 2 \mathrm{H}) \mathrm{ppm} .{ }^{13} \mathrm{C} \mathrm{NMR}\left(\mathrm{CDCl}_{3}\right): \delta=$ $164.0(\mathrm{C}=\mathrm{N}), 162.0(\mathrm{C}), 153.1(\mathrm{C}), 136.8(\mathrm{C}), 134.5(\mathrm{C}), 132.5(\mathrm{C})$, 131.3 (C), 130.8 (C), 130.7 (C), $130.2(\mathrm{CH}), 129.7(\mathrm{CH}), 129.6$ $(\mathrm{CH}), 129.5(\mathrm{CH}), 129.3(\mathrm{CH}), 129.0(\mathrm{CH}), 128.8(\mathrm{CH}), 128.7(\mathrm{CH})$, $128.6(\mathrm{CH}), 128.1(\mathrm{CH}), 127.6(\mathrm{CH}), 127.4(\mathrm{CH}), 127.3(\mathrm{CH}), 126.3$ $(\mathrm{CH}), 126.2(\mathrm{CH}), 126.0(\mathrm{CH}), 125.9(\mathrm{CH}), 125.7(\mathrm{CH}), 125.6(\mathrm{CH})$, $124.9(\mathrm{CH}), 124.7$ (CH), 124.3 (C), 124.0 (C), 116.7 (C), 106.0 (CN) ppm. Elemental analysis: calcd for $\mathrm{C}_{44} \mathrm{H}_{23} \mathrm{ClN}_{2}$ : C, 85.91; $\mathrm{H}, 3.77$; N, 4.55; Cl, 5.76; found: C, 85.66; H, 3.70; N, 4.42; Cl, 5.59 .

\section{4-(4-Cyanophenyl)-2,6-di(pyren-1-yl)nicotinonitrile} (6e). Orange crystals; yield (95\%), $\mathrm{mp}>310^{\circ} \mathrm{C}$. FT-IR (KBr): $\nu_{\max }=$ 3040 (CH arom.), 2208, $2200(\mathrm{CN}), 1610(\mathrm{C}=\mathrm{N}) \mathrm{cm}^{-1} \cdot{ }^{1} \mathrm{H}$ NMR $\left(\mathrm{CDCl}_{3}\right): \delta=8.69(\mathrm{~d}, J=9.0 \mathrm{~Hz}, 1 \mathrm{H}), 8.41-8.38(\mathrm{~m}, 3 \mathrm{H}), 8.32(\mathrm{~d}, J$ $=9.0 \mathrm{~Hz}, 1 \mathrm{H}), 8.30-8.27(\mathrm{~m}, 4 \mathrm{H}), 8.25(\mathrm{~d}, J=7.5 \mathrm{~Hz}, 2 \mathrm{H}), 8.22-$ $8.19(\mathrm{~m}, 4 \mathrm{H}), 8.15(\mathrm{~d}, J=9.0 \mathrm{~Hz}, 1 \mathrm{H}), 8.11(\mathrm{~d}, J=7.5 \mathrm{~Hz}, 1 \mathrm{H})$, 8.07 (d, $J=7.5 \mathrm{~Hz}, 2 \mathrm{H}), 8.01(\mathrm{~d}, J=8.0 \mathrm{~Hz}, 2 \mathrm{H}), 7.94(\mathrm{~d}, J=$ $8.0 \mathrm{~Hz}, 2 \mathrm{H}) \mathrm{ppm} .{ }^{13} \mathrm{C} \mathrm{NMR}\left(\mathrm{CDCl}_{3}\right): \delta=164.3(\mathrm{C}=\mathrm{N}), 162.9(\mathrm{C})$, 152.3 (C), 141.0 (C), 136.8 (C), 133.2 (C), 132.9 (C), 132.5 (C), 
131.6 (C), 131.1 (C), 130.0 (CH), $129.8(\mathrm{CH}), 129.2(\mathrm{CH}), 129.0$ $(\mathrm{CH}), 128.9(\mathrm{CH}), 128.8(\mathrm{CH}), 128.1(\mathrm{CH}), 127.9(\mathrm{CH}), 127.5(\mathrm{CH})$, $127.4(\mathrm{CH}), 126.5(\mathrm{CH}), 126.4(\mathrm{CH}), 126.2(\mathrm{CH}), 126.1(\mathrm{CH}), 125.9$ $(\mathrm{CH}), 125.8(\mathrm{CH}), 125.1(\mathrm{CH}), 124.9(\mathrm{CH}), 124.2(\mathrm{CH}), 124.1(\mathrm{CH})$, 124.0 (CH), 118.4 (C), 118.3 (C), 116.8 (C), 114.4 (C), 107.5 (CN) ppm. Elemental analysis: calcd for $\mathrm{C}_{45} \mathrm{H}_{23} \mathrm{~N}_{3}$ : C, 89.23; $\mathrm{H}$, 3.83 ; N, 6.94; found: C, 89.00; H, 3.69; N, 6.80.

4-(4-Nitrophenyl)-2,6-di(pyren-1-yl)nicotinonitrile (6f). Red crystals; yield (90\%), mp 292-293 ${ }^{\circ} \mathrm{C}$. FT-IR (KBr): $\nu_{\max }=3040$ (CH arom.), $2210(\mathrm{CN}), 1615(\mathrm{C}=\mathrm{N}) \mathrm{cm}^{-1} \cdot{ }^{1} \mathrm{H} \mathrm{NMR}\left(\mathrm{CDCl}_{3}\right): \delta=$ 8.69 (d, $1 \mathrm{H}, J=9.0 \mathrm{~Hz}, 1 \mathrm{H}), 8.50$ (d, $J=8.5 \mathrm{~Hz}, 2 \mathrm{H}), 8.42-8.39$ $(\mathrm{m}, 3 \mathrm{H}), 8.33(\mathrm{~d}, J=8.5 \mathrm{~Hz}, 1 \mathrm{H}), 8.30-8.25(\mathrm{~m}, 7 \mathrm{H}), 8.21-8.17$ $(\mathrm{m}, 4 \mathrm{H}), 8.15$ (d, $J=9.0 \mathrm{~Hz}, 1 \mathrm{H}), 8.11-8.06(\mathrm{~m}, 4 \mathrm{H}) \mathrm{ppm} .{ }^{13} \mathrm{C}$ NMR $\left(\mathrm{CDCl}_{3}\right): \delta=164.6(\mathrm{C}=\mathrm{N}), 162.9(\mathrm{C}), 152.0(\mathrm{C}), 149.1(\mathrm{C})$, 142.7 (C), 132.9 (C), 131.6 (C), 131.1 (C), $130.4(\mathrm{C}), 130.2(\mathrm{CH})$, $129.3(\mathrm{CH}), 129.1(\mathrm{CH}), 129.0(\mathrm{CH}), 128.9(\mathrm{CH}), 128.2(\mathrm{CH}), 127.7$ $(\mathrm{CH}), 127.5(\mathrm{CH}), 127.4(\mathrm{CH}), 126.5(\mathrm{CH}), 126.4(\mathrm{CH}), 126.2(\mathrm{CH})$, $126.1(\mathrm{CH}), 125.8(\mathrm{CH}), 125.7(\mathrm{CH}), 125.1(\mathrm{CH}), 124.9(\mathrm{CH}), 124.5$ $(\mathrm{CH}), 124.2(\mathrm{CH}), 124.1(\mathrm{CH}), 124.0(\mathrm{CH}), 116.7(\mathrm{C}), 107.5$ (CN) ppm. Elemental analysis: calcd for $\mathrm{C}_{44} \mathrm{H}_{23} \mathrm{~N}_{3} \mathrm{O}_{2}$ : C, 84.46; $\mathrm{H}, 3.71$; N, 6.72; found: C, 84.29; H, 3.58; N, 6.63.

2,6-Di(9H-fluoren-2-yl)-4-phenylnicotinonitrile (7a). Yellow crystals; yield (97\%), mp 240-241 ${ }^{\circ} \mathrm{C}$. FT-IR (KBr): $\nu_{\max }=3053$ (CH arom.), $2218(\mathrm{CN}), 1612(\mathrm{C}=\mathrm{N}) \mathrm{cm}^{-1} \cdot{ }^{1} \mathrm{H} \mathrm{NMR}\left(\mathrm{CDCl}_{3}\right): \delta=$ 8.45 (s, 1H), 8.27-8.23 (m, 1H), 8.14-8.09 (m, 2H), 8.01-7.99 (m, 2H), 7.93-7.82 (m, 4H), $7.75(\mathrm{~s}, 1 \mathrm{H}), 7.68(\mathrm{~d}, J=15.0 \mathrm{~Hz}, 2 \mathrm{H})$, $7.62-7.57(\mathrm{~m}, 2 \mathrm{H}), 7.45-7.41(\mathrm{~m}, 5 \mathrm{H}), 4.06\left(\mathrm{~d},{ }^{2} J=21.0 \mathrm{~Hz}, 2 \mathrm{H}\right.$, $\left.\mathrm{CH}_{2}\right), 3.96$ (d, $\left.{ }^{2} J=19.5 \mathrm{~Hz}, 2 \mathrm{H}, \mathrm{CH}_{2}\right) \mathrm{ppm} .{ }^{13} \mathrm{C} \mathrm{NMR}\left(\mathrm{CDCl}_{3}\right): \delta=$ $162.6(\mathrm{C}=\mathrm{N}), 159.3(\mathrm{C}), 155.4(\mathrm{C}), 146.7$ (C), 144.5 (C), $144.4(\mathrm{C})$, 144.0 (C), 143.7 (C), 143.4 (C), 140.9 (C), 136.7 (C), 135.0 (C), $132.4(\mathrm{C}), 130.5(\mathrm{CH}), 129.3(\mathrm{CH}), 129.1(\mathrm{CH}), 129.0(\mathrm{CH}), 128.9$ $(\mathrm{CH}), 128.8(\mathrm{CH}), 128.7(\mathrm{CH}), 128.4(\mathrm{CH}), 128.0(\mathrm{CH}), 127.9(\mathrm{CH})$, $127.1(\mathrm{CH}), 125.3(\mathrm{CH}), 125.2(\mathrm{CH}), 125.1(\mathrm{CH}), 122.2(\mathrm{CH}), 120.9$ $(\mathrm{CH}), 120.6(\mathrm{CH}), 119.7(\mathrm{CH}), 104.0(\mathrm{CN}), 37.0\left(\mathrm{CH}_{2}\right), 36.9$ $\left(\mathrm{CH}_{2}\right)$ ppm. Elemental analysis: calcd for $\mathrm{C}_{38} \mathrm{H}_{24} \mathrm{~N}_{2}$ : C, 89.74; $\mathrm{H}$, 4.76; N, 5.51; found: C, 89.50; H, 4.58; N, 5.39.

\section{4-(4-(Dimethylamino)phenyl)-2,6-di(9H-fluoren-2-yl)}

nicotinonitrile (7b). Yellow crystals; yield (83\%), mp 200$201{ }^{\circ} \mathrm{C}$. FT-IR (KBr): $\nu_{\max }=3052$ (CH arom.), 2217 (CN), 1612 $(\mathrm{C}=\mathrm{N}) \mathrm{cm}^{-1} \cdot{ }^{1} \mathrm{H} \mathrm{NMR}\left(\mathrm{CDCl}_{3}\right): \delta=8.43(\mathrm{~d}, 1 \mathrm{H}, J=10 \mathrm{~Hz}, 1 \mathrm{H})$, $8.32(\mathrm{~s}, 1 \mathrm{H}), 8.25(\mathrm{~s}, 1 \mathrm{H}), 8.19(\mathrm{~d}, J=10.5 \mathrm{~Hz}, 2 \mathrm{H}), 8.11(\mathrm{~s}, 1 \mathrm{H})$, 7.99-7.97 (m, 2H), 7.93-7.84 (m, 2H), 7.76-7.74 (m, 2H), 7.63$7.61(\mathrm{~m}, 3 \mathrm{H}), 7.44-7.39(\mathrm{~m}, 4 \mathrm{H}), 4.06\left(\mathrm{~s}, 2 \mathrm{H}, \mathrm{CH}_{2}\right), 4.00\left(\mathrm{~d},{ }^{2} J=\right.$ $\left.19.0 \mathrm{~Hz}, 2 \mathrm{H}, \mathrm{CH}_{2}\right), 3.14\left(\mathrm{~s}, 6 \mathrm{H}, 2 \mathrm{CH}_{3}\right) \mathrm{ppm} .{ }^{13} \mathrm{C} \mathrm{NMR}\left(\mathrm{CDCl}_{3}\right)$ : $\delta=162.9(\mathrm{C}=\mathrm{N}), 162.5(\mathrm{C}), 159.2(\mathrm{C}), 147.8(\mathrm{C}), 144.2(\mathrm{C}), 144.1$ (C), 144.0 (C), 143.8 (C), 141.0 (C), 140.9 (C), 140.5 (C), 134.2 (C), $130.2(\mathrm{CH}), 128.5(\mathrm{CH}), 128.4(\mathrm{CH}), 128.0(\mathrm{CH}), 126.9(\mathrm{CH}), 126.1$ $(\mathrm{CH}), 125.9(\mathrm{CH}), 125.3(\mathrm{CH}), 125.2(\mathrm{CH}), 125.1(\mathrm{CH}), 120.9(\mathrm{CH})$, $120.8(\mathrm{CH}), 120.5(\mathrm{CH}), 120.4(\mathrm{CH}), 120.2(\mathrm{CH}), 119.7(\mathrm{CH}), 117.8$ (CH), 116.6 (C), $104.4(\mathrm{CN}), 43.6\left(\mathrm{CH}_{3}\right), 37.1\left(\mathrm{CH}_{2}\right), 37.0$ $\left(\mathrm{CH}_{2}\right)$ ppm. Elemental analysis: calcd for $\mathrm{C}_{40} \mathrm{H}_{29} \mathrm{~N}_{3}: \mathrm{C}, 87.08 ; \mathrm{H}$, 5.30 ; N, 7.62; found: C, 86.80; H, 5.11; N, 7.50.

2,6-Di(9H-fluoren-2-yl)-4-(4-methoxyphenyl)nicotinonitrile (7c). Pale yellow crystals; yield (98\%), mp 269-270 ${ }^{\circ} \mathrm{C}$. FT-IR $(\mathrm{KBr}): \nu_{\max }=3050$ (CH arom.), $2210(\mathrm{CN}), 1610(\mathrm{C}=\mathrm{N}) \mathrm{cm}^{-1}$. ${ }^{1} \mathrm{H} \mathrm{NMR}\left(\mathrm{CDCl}_{3}\right): \delta=8.43(\mathrm{~s}, 1 \mathrm{H}), 8.25(\mathrm{~d}, J=8.5 \mathrm{~Hz}, 1 \mathrm{H}), 8.14$ (s, 1H), 7.99-7.97 (m, 1H), 7.93-7.83 (m, 3H), 7.72 (s, 1H), 7.63- $7.61(\mathrm{~m}, 3 \mathrm{H}), 7.44-7.39(\mathrm{~m}, 6 \mathrm{H}), 7.12-7.10(\mathrm{~m}, 1 \mathrm{H}), 7.02(\mathrm{~m}, 1 \mathrm{H})$, $4.06\left(\mathrm{~d},{ }^{2} J=19.5 \mathrm{~Hz}, 2 \mathrm{H}, \mathrm{CH}_{2}\right), 3.96-3.87\left(\mathrm{~m}, 5 \mathrm{H}, \mathrm{CH}_{2}\right.$, $\left.\mathrm{CH}_{3}\right)$ ppm. ${ }^{13} \mathrm{C} \mathrm{NMR}\left(\mathrm{CDCl}_{3}\right): \delta=162.6(\mathrm{C}=\mathrm{N}), 161.1(\mathrm{C}), 159.6$ (C), 159.1 (C), 147.4 (C), 144.9 (C), 144.2 (C), 144.1 (C), 144.0 (C), 143.7 (C), 141.0 (C), 140.9 (C), 140.3 (C), 130.5 (C), 130.3 (C), $128.9(\mathrm{CH}), 128.5(\mathrm{CH}), 127.9(\mathrm{CH}), 127.5(\mathrm{CH}), 127.4(\mathrm{CH}), 127.1$ $(\mathrm{CH}), 126.4(\mathrm{CH}), 126.2(\mathrm{CH}), 125.2(\mathrm{CH}), 125.1(\mathrm{CH}), 124.4(\mathrm{CH})$, $120.6(\mathrm{CH}), 120.5(\mathrm{CH}), 120.2(\mathrm{CH}), 119.8(\mathrm{CH}), 114.7(\mathrm{CH}), 114.5$ $(\mathrm{CH}), 103.2(\mathrm{CN}), 55.5\left(\mathrm{CH}_{3}\right), 37.1\left(\mathrm{CH}_{2}\right), 36.9\left(\mathrm{CH}_{2}\right)$ ppm. Elemental analysis: calcd for $\mathrm{C}_{39} \mathrm{H}_{26} \mathrm{~N}_{2} \mathrm{O}$ : C, 86.96; $\mathrm{H}, 4.87$; , 5.20; found: C, 86.70; H, 4.59; N, 4.95.

4-(4-Chlorophenyl)-2,6-di(9H-fluoren-2-yl)nicotinonitrile

(7d). Yellow crystals; yield (80\%), mp 289-290 ${ }^{\circ} \mathrm{C}$. FT-IR (KBr): $\nu_{\max }=3039$ (CH arom.), $2200(\mathrm{CN}), 1615(\mathrm{C}=\mathrm{N}) \mathrm{cm}^{-1} \cdot{ }^{1} \mathrm{H} \mathrm{NMR}$ $\left(\mathrm{CDCl}_{3}\right): \delta=8.45(\mathrm{~s}, 1 \mathrm{H}), 8.25(\mathrm{~d}, J=14.0 \mathrm{~Hz}, 2 \mathrm{H}), 8.12(\mathrm{~s}, 1 \mathrm{H})$, $8.00(\mathrm{~s}, 1 \mathrm{H}), 7.94-7.82(\mathrm{~m}, 4 \mathrm{H}), 7.70-7.68(\mathrm{~m}, 1 \mathrm{H}), 7.60(\mathrm{~d}, J=$ $14.0 \mathrm{~Hz}, 4 \mathrm{H}), 7.47-7.40(\mathrm{~m}, 5 \mathrm{H}), 4.06\left(\mathrm{~d},{ }^{2} J=20.0 \mathrm{~Hz}, 2 \mathrm{H}, \mathrm{CH}_{2}\right)$, $3.98\left(\mathrm{~s}, 2 \mathrm{H}, \mathrm{CH}_{2}\right) \mathrm{ppm} .{ }^{13} \mathrm{C} \mathrm{NMR}\left(\mathrm{CDCl}_{3}\right): \delta=162.7(\mathrm{C}=\mathrm{N}), 159.5$ (C), 154.2 (C), 147.9 (C), 145.1 (C), 144.3 (C), 144.0 (C), 143.5 (C), 140.9 (C), 140.8 (C), 140.2 (C), 136.3 (C), 136.1 (C), 135.7 (C), $135.5(\mathrm{C}), 130.1(\mathrm{CH}), 129.5(\mathrm{CH}), 129.3(\mathrm{CH}), 129.1(\mathrm{CH}), 128.4$ $(\mathrm{CH}), 128.1(\mathrm{CH}), 127.6(\mathrm{CH}), 127.4(\mathrm{CH}), 127.2(\mathrm{CH}), 127.0(\mathrm{CH})$, $126.9(\mathrm{CH}), 126.3(\mathrm{CH}), 126.1(\mathrm{CH}), 125.2(\mathrm{CH}), 125.1(\mathrm{CH}), 124.3$ (CH), $120.6(\mathrm{CH}), 120.5(\mathrm{CH}), 119.9(\mathrm{CH}), 117.8(\mathrm{C}), 103.7(\mathrm{CN})$, $37.1\left(\mathrm{CH}_{2}\right), 36.9\left(\mathrm{CH}_{2}\right)$ ppm. Elemental analysis: calcd for $\mathrm{C}_{38} \mathrm{H}_{23} \mathrm{ClN}_{2}$ : C, 84.04; H, 4.27; N, 5.16; Cl, 6.53; found: C, 83.86; $\mathrm{H}, 4.05$; N, 5.02; Cl, 6.30 .

4-(4-Cyanophenyl)-2,6-di(9H-fluoren-2-yl)nicotinonitrile (7e). Yellow crystals; yield (87\%), mp $>310{ }^{\circ} \mathrm{C}$. FT-IR $(\mathrm{KBr}): \nu_{\max }=$ 3039 (CH arom.), 2218, $2201(\mathrm{CN}), 1612(\mathrm{C}=\mathrm{N}) \mathrm{cm}^{-1} \cdot{ }^{1} \mathrm{H}$ NMR $\left(\mathrm{CDCl}_{3}\right): \delta=8.45(\mathrm{~s}, 1 \mathrm{H}), 8.25(\mathrm{~m}, 1 \mathrm{H}), 8.14(\mathrm{~d}, J=8.0 \mathrm{~Hz}, 1 \mathrm{H})$, $8.01(\mathrm{~d}, J=8.0 \mathrm{~Hz}, 1 \mathrm{H}), 7.96(\mathrm{~d}, J=8.0 \mathrm{~Hz}, 1 \mathrm{H}), 7.93-7.88(\mathrm{~m}$, $4 \mathrm{H}), 7.87-7.85(\mathrm{~m}, 2 \mathrm{H}), 7.82(\mathrm{~d}, J=8.0 \mathrm{~Hz}, 1 \mathrm{H}), 7.67-7.61(\mathrm{~m}$, $3 \mathrm{H}), 7.47-7.44(\mathrm{~m}, 2 \mathrm{H}), 7.43-7.39(\mathrm{~m}, 2 \mathrm{H}), 4.08\left(\mathrm{~s}, 2 \mathrm{H}, \mathrm{CH}_{2}\right), 4.00$ $\left(\mathrm{d},{ }^{2} J=24.0 \mathrm{~Hz}, 2 \mathrm{H}, \mathrm{CH}_{2}\right) \mathrm{ppm} .{ }^{13} \mathrm{C} \mathrm{NMR}\left(\mathrm{CDCl}_{3}\right): \delta=163.1(\mathrm{C}=$ N), 160.1 (C), 153.7 (C), 148.8 (C), 145.7 (C), 145.0 (C), 144.4 (C), 144.3 (C), 143.9 (C), 141.6 (C), 141.2 (C), 140.4 (C), 136.0 (C), $135.6(\mathrm{C}), 133.6(\mathrm{CH}), 133.1(\mathrm{CH}), 129.9(\mathrm{CH}), 128.8(\mathrm{CH}), 128.1$ $(\mathrm{CH}), 127.9(\mathrm{CH}), 127.4(\mathrm{CH}), 127.3(\mathrm{CH}), 126.4(\mathrm{CH}), 125.6(\mathrm{CH})$, $125.5(\mathrm{CH}), 124.5(\mathrm{CH}), 121.0(\mathrm{CH}), 120.9(\mathrm{CH}), 120.3(\mathrm{CH}), 120.1$ (CH), 118.4 (C), 114.1 (C), 103.8 (CN), $37.4\left(\mathrm{CH}_{2}\right), 37.3$ $\left(\mathrm{CH}_{2}\right)$ ppm. Elemental analysis: calcd for $\mathrm{C}_{39} \mathrm{H}_{23} \mathrm{~N}_{3}: \mathrm{C}, 87.78 ; \mathrm{H}$, 4.34; N, 7.87; found: C, 87.70; H, 4.21; N, 7.69.

2,6-Di(9H-fluoren-2-yl)-4-(4-nitrophenyl)nicotinonitrile (7f). Yellow crystals; yield (85\%), $\operatorname{mp} 252-254^{\circ} \mathrm{C}$. FT-IR $(\mathrm{KBr}): \nu_{\max }=$ 3041 (CH arom.), $2200(\mathrm{CN}), 1612(\mathrm{C}=\mathrm{N}) \mathrm{cm}^{-1} \cdot{ }^{1} \mathrm{H}$ NMR $\left(\mathrm{CDCl}_{3}\right): \delta=8.46(\mathrm{~d}, J=7.5 \mathrm{~Hz}, 2 \mathrm{H}), 8.38(\mathrm{~s}, 1 \mathrm{H}), 8.29-8.25(\mathrm{~m}$, $1 \mathrm{H}), 8.14(\mathrm{~s}, 1 \mathrm{H}), 8.01(\mathrm{~s}, 1 \mathrm{H}), 7.95-7.83(\mathrm{~m}, 5 \mathrm{H}), 7.73-7.63(\mathrm{~m}$, $4 \mathrm{H}), 7.49-7.41(\mathrm{~m}, 4 \mathrm{H}), 4.06\left(\mathrm{~s},{ }^{2} J=21.0 \mathrm{~Hz}, 2 \mathrm{H}, \mathrm{CH}_{2}\right), 4.01(\mathrm{~s}$, $\left.2 \mathrm{H}, \mathrm{CH}_{2}\right) \cdot{ }^{13} \mathrm{C} \mathrm{NMR}\left(\mathrm{CDCl}_{3}\right): \delta=162.8(\mathrm{C}=\mathrm{N}), 159.8(\mathrm{C}), 152.7$ (C), 148.6 (C), 145.4 (C), 144.6 (C), 144.3 (C), 144.1 (C), 144.0 (C), 143.7 (C), 143.6 (C), 143.1 (C), 140.8 (C), 140.1 (C), 135.8 (C), $129.9(\mathrm{CH}), 128.7(\mathrm{CH}), 128.4(\mathrm{CH}), 128.2(\mathrm{CH}), 127.7(\mathrm{CH}), 127.6$ $(\mathrm{CH}), 127.2(\mathrm{CH}), 127.1(\mathrm{CH}), 127.0(\mathrm{CH}), 126.3(\mathrm{CH}), 126.0(\mathrm{CH})$, $125.3(\mathrm{CH}), 125.2(\mathrm{CH}), 124.7(\mathrm{CH}), 124.3(\mathrm{CH}), 120.7(\mathrm{C}), 120.6$ $(\mathrm{CH}), 120.3(\mathrm{CH}), 119.9(\mathrm{CH}), 117.4(\mathrm{C}), 103.4(\mathrm{CN}), 37.1\left(\mathrm{CH}_{2}\right)$, 
$36.9\left(\mathrm{CH}_{2}\right)$ ppm. Elemental analysis: calcd for $\mathrm{C}_{38} \mathrm{H}_{23} \mathrm{~N}_{3} \mathrm{O}_{2}$ : C, 82.44; H, 4.19; N, 7.59; found: C, 82.31; H, 4.22; N, 7.61.

6-(9H-Fluoren-2-yl)-4-phenyl-2-(pyren-1-yl)nicotinonitrile

(8a). Yellow crystals; yield (85\%), mp 225-226 ${ }^{\circ} \mathrm{C}$. FT-IR (KBr): $\nu_{\max }=3045$ (CH arom.), $2210(\mathrm{CN}), 1615(\mathrm{C}=\mathrm{N}) \mathrm{cm}^{-1} \cdot{ }^{1} \mathrm{H}$ NMR $\left(\mathrm{CDCl}_{3}\right): \delta=8.46(\mathrm{~s}, 1 \mathrm{H}), 8.36(\mathrm{~d}, J=14.5 \mathrm{~Hz}, 2 \mathrm{H}), 8.28-8.25(\mathrm{~m}$, $3 \mathrm{H}), 8.21-8.19$ (m, 4H), 8.10-8.08 (m, 2H), 7.92 (s, 1H), 7.88-7.85 $(\mathrm{m}, 3 \mathrm{H}), 7.63-7.60(\mathrm{~m}, 4 \mathrm{H}), 7.43-7.38(\mathrm{~m}, 2 \mathrm{H}), 3.98(\mathrm{~s}, 2 \mathrm{H}$, $\left.\mathrm{CH}_{2}\right)$ ppm. ${ }^{13} \mathrm{C} \mathrm{NMR}\left(\mathrm{CDCl}_{3}\right): \delta=163.7(\mathrm{C}=\mathrm{N}), 159.3(\mathrm{C}), 154.7$ (C), 144.2 (C), 144.1 (C), 144.0 (C), 140.8 (C), 136.7 (C), 132.0 (C), $130.8(\mathrm{C}), 130.0(\mathrm{CH}), 129.1(\mathrm{CH}), 128.7(\mathrm{CH}), 128.5(\mathrm{CH}), 127.5$ $(\mathrm{CH}), 127.4(\mathrm{CH}), 127.0(\mathrm{CH}), 126.7(\mathrm{CH}), 126.2(\mathrm{CH}), 125.8(\mathrm{CH})$, $125.5(\mathrm{CH}), 125.2(\mathrm{CH}), 124.6(\mathrm{CH}), 124.5(\mathrm{CH}), 124.4(\mathrm{CH}), 120.5$ $(\mathrm{CH}), 120.3(\mathrm{CH}), 118.8(\mathrm{CH}), 117.2(\mathrm{C}), 107.2(\mathrm{CN}), 37.0$ $\left(\mathrm{CH}_{2}\right)$ ppm. Elemental analysis: calcd for $\mathrm{C}_{41} \mathrm{H}_{24} \mathrm{~N}_{2}$ : C, 90.42; $\mathrm{H}$, 4.44; N, 5.14; found: C, 90.33; H, 4.31; N, 4.97.

4-(4-(Dimethylamino)phenyl)-6-(9H-fluoren-2-yl)-2-(pyren-1yl)nicotinonitrile (8b). Red crystals; yield (81\%), mp 170-171 ${ }^{\circ} \mathrm{C}$. FT-IR (KBr): $\nu_{\max }=3044$ (CH arom.), $2207(\mathrm{CN}), 1611(\mathrm{C}=$ $\mathrm{N}) \mathrm{cm}^{-1} \cdot{ }^{1} \mathrm{H}$ NMR $\left(\mathrm{CDCl}_{3}\right): \delta=8.34(\mathrm{~d}, J=6.0 \mathrm{~Hz}, 1 \mathrm{H}), 8.30-8.24$ $(\mathrm{m}, 3 \mathrm{H}), 8.22-8.13(\mathrm{~m}, 4 \mathrm{H}), 8.11-8.06(\mathrm{~m}, 3 \mathrm{H}), 7.99-7.90(\mathrm{~m}$, $5 \mathrm{H}), 7.83(\mathrm{~s}, 1 \mathrm{H}), 7.60-7.42(\mathrm{~m}, 2 \mathrm{H}), 6.63(\mathrm{~d}, J=7.0 \mathrm{~Hz}, 2 \mathrm{H}), 3.94$ $\left(\mathrm{s}, 2 \mathrm{H}, \mathrm{CH}_{2}\right), 3.07\left(\mathrm{~s}, 6 \mathrm{H}, 2 \mathrm{CH}_{3}\right)$ ppm. ${ }^{13} \mathrm{C} \mathrm{NMR}\left(\mathrm{CDCl}_{3}\right): \delta=$ $156.1(\mathrm{C}=\mathrm{N}), 153.9(\mathrm{C}), 146.4(\mathrm{C}), 144.5(\mathrm{C}), 143.3(\mathrm{C}), 140.4(\mathrm{C})$, 134.7 (CH), 133.0 (C), 132.3 (C), 131.1 (C), 130.6 (C), 129.2 (C), $129.1(\mathrm{CH}), 129.0(\mathrm{CH}), 128.0(\mathrm{CH}), 127.7(\mathrm{CH}), 127.2(\mathrm{CH}), 127.0$ $(\mathrm{CH}), 126.4(\mathrm{CH}), 126.1(\mathrm{CH}), 125.9(\mathrm{CH}), 125.7(\mathrm{CH}), 125.2(\mathrm{CH})$, $124.9(\mathrm{CH}), 124.3(\mathrm{CH}), 124.0(\mathrm{CH}), 120.9(\mathrm{CH}), 119.6(\mathrm{C}), 118.6$ (C), $111.6(\mathrm{CH}), 104.3(\mathrm{CN}), 40.0\left(\mathrm{CH}_{3}\right), 36.9\left(\mathrm{CH}_{2}\right)$ ppm. Elemental analysis: calcd for $\mathrm{C}_{43} \mathrm{H}_{29} \mathrm{~N}_{3}$ : C, 87.88; H, 4.97; N, 7.15; found: C, 87.76; H, 4.78; N, 6.99.

6-(9H-Fluoren-2-yl)-4-(4-methoxyphenyl)-2-(pyren-1-yl)

nicotinonitrile (8c). Yellow crystals; yield (94\%), mp 185-187 ${ }^{\circ} \mathrm{C}$. FT-IR (KBr): $\nu_{\max }=3045$ (CH arom.), $2207(\mathrm{CN}), 1612(\mathrm{C}=$ N) $\mathrm{cm}^{-1} \cdot{ }^{1} \mathrm{H}$ NMR $\left(\mathrm{CDCl}_{3}\right): \delta=8.55(\mathrm{~d}, J=5.0 \mathrm{~Hz}, 1 \mathrm{H}), 8.33-8.31$ (m, 2H), 8.27-8.25 (m, 2H), 8.18-8.15 (m, 4H), 8.08 (s, 1H), 7.99$7.97(\mathrm{~m}, 1 \mathrm{H}), 7.88-7.86(\mathrm{~m}, 2 \mathrm{H}), 7.79(\mathrm{~d}, J=7.5 \mathrm{~Hz}, 2 \mathrm{H}), 7.62-$ 7.59 (m, 2H), 7.45-7.43 (m, 1H), 7.39-7.37 (m, 1H), 7.12 (d, $J=$ $7.5 \mathrm{~Hz}, 2 \mathrm{H}), 4.05\left(\mathrm{~s}, 2 \mathrm{H}, \mathrm{CH}_{2}\right), 3.92\left(\mathrm{~s}, 3 \mathrm{H}, \mathrm{CH}_{3}\right) \mathrm{ppm} .{ }^{13} \mathrm{C} \mathrm{NMR}$ $\left(\mathrm{CDCl}_{3}\right): \delta=162.9(\mathrm{C}=\mathrm{N}), 161.2(\mathrm{C}), 154.8(\mathrm{C}), 144.0(\mathrm{C}), 143.5$ (C), 140.9 (C), 132.2 (C), 131.3 (C), 130.8 (C), $130.4(\mathrm{CH}), 128.7$ $(\mathrm{CH}), 128.6(\mathrm{CH}), 127.8(\mathrm{CH}), 127.4(\mathrm{CH}), 127.3(\mathrm{CH}), 126.9(\mathrm{CH})$, $126.3(\mathrm{CH}), 125.9(\mathrm{CH}), 125.4(\mathrm{CH}), 125.1(\mathrm{CH}), 124.9(\mathrm{CH}), 124.2$ $(\mathrm{CH}), 123.8(\mathrm{CH}), 120.5(\mathrm{CH}), 119.9(\mathrm{CH}), 118.4(\mathrm{C}), 114.5(\mathrm{CH})$, $104.1(\mathrm{CN}), 55.5\left(\mathrm{CH}_{3}\right), 37.1\left(\mathrm{CH}_{2}\right) \mathrm{ppm}$. Elemental analysis: calcd for $\mathrm{C}_{42} \mathrm{H}_{26} \mathrm{~N}_{2} \mathrm{O}$ : C, 87.78; $\mathrm{H}, 4.56 ; \mathrm{N}, 4.87$; found: C, 87.60; $\mathrm{H}, 4.44 ; \mathrm{N}, 4.69$.

4-(4-Chlorophenyl)-6-(9H-fluoren-2-yl)-2-(pyren-1-yl)

nicotinonitrile (8d). Yellow crystals; yield (82\%), mp 280$282{ }^{\circ} \mathrm{C}$. FT-IR (KBr): $\nu_{\max }=3045$ (CH arom.), $2206(\mathrm{CN}), 1612$ $(\mathrm{C}=\mathrm{N}) \mathrm{cm}^{-1} \cdot{ }^{1} \mathrm{H} \mathrm{NMR}\left(\mathrm{CDCl}_{3}\right): \delta=8.45(\mathrm{~s}, 1 \mathrm{H}), 8.37(\mathrm{~s}, 1 \mathrm{H})$, 8.33-8.26 (m, 4H), 8.20-8.17 (m, 4H), 8.09-8.05 (m, 3H), 7.927.87 (m, 2H), 7.79-7.77 (m, 1H), 7.62-7.59 (m, 2H), 7.44-7.38 $(\mathrm{m}, 2 \mathrm{H}), 7.30-7.28(\mathrm{~m}, 1 \mathrm{H}), 3.98\left(\mathrm{~s}, 2 \mathrm{H}, \mathrm{CH}_{2}\right) \mathrm{ppm} .{ }^{13} \mathrm{C} \mathrm{NMR}$ $\left(\mathrm{CDCl}_{3}\right): \delta=163.5(\mathrm{C}=\mathrm{N}), 159.7(\mathrm{C}), 144.2(\mathrm{C}), 144.1$ (C), 141.0 (C), 135.7 (C), $135.1(\mathrm{C}), 130.1(\mathrm{CH}), 129.4(\mathrm{CH}), 128.6(\mathrm{CH})$, $128.0(\mathrm{CH}), 127.6(\mathrm{CH}), 127.5(\mathrm{C}), 127.4(\mathrm{CH}), 127.0(\mathrm{CH}), 126.7$
$(\mathrm{CH}), 126.2(\mathrm{CH}), 125.8(\mathrm{CH}), 125.5(\mathrm{CH}), 125.2(\mathrm{CH}), 124.6(\mathrm{CH})$, $124.4(\mathrm{CH}), 124.3(\mathrm{CH}), 120.9(\mathrm{CH}), 120.6(\mathrm{CH}), 120.3(\mathrm{CH}), 119.6$ $(\mathrm{CH}), 118.6(\mathrm{C}), 118.5(\mathrm{CH}), 116.9(\mathrm{C}), 107.9(\mathrm{CN}), 37.0$ $\left(\mathrm{CH}_{2}\right)$ ppm. Elemental analysis: calcd for $\mathrm{C}_{41} \mathrm{H}_{23} \mathrm{ClN}_{2}$ : C, 85.04; $\mathrm{H}, 4.00 ; \mathrm{N}, 4.84$; Cl, 6.12; found: C, 84.96; H, 4.09; N, 4.78; Cl, 6.04 .

4-(4-Cyanophenyl)-6-(9H-fluoren-2-yl)-2-(pyren-1-yl)

nicotinonitrile (8e). Yellow crystals; yield (91\%), $\mathrm{mp}>310{ }^{\circ} \mathrm{C}$. FT-IR (KBr): $\nu_{\max }=3045$ (CH arom.), $2200(\mathrm{CN}), 1612(\mathrm{C}=$ N) $\mathrm{cm}^{-1} \cdot{ }^{1} \mathrm{H} \mathrm{NMR}\left(\mathrm{CDCl}_{3}\right): \delta=8.46(\mathrm{~s}, 1 \mathrm{H}), 8.38(\mathrm{~s}, 1 \mathrm{H}), 8.30-$ $8.27(\mathrm{~m}, 4 \mathrm{H}), 8.21-8.18(\mathrm{~m}, 4 \mathrm{H}), 8.10-8.05(\mathrm{~m}, 2 \mathrm{H}), 7.94-7.87$ (m, 6H), 7.60-7.58 (m, 1H), 7.44-7.39 (m, 2H), $3.99(\mathrm{~s}, 2 \mathrm{H}$, $\left.\mathrm{CH}_{2}\right) \mathrm{ppm} .{ }^{13} \mathrm{C} \mathrm{NMR}\left(\mathrm{CDCl}_{3}\right): \delta=160.5(\mathrm{C}=\mathrm{N}), 160.1(\mathrm{C}), 153.0$ (C), 145.0 (C), 144.4 (C), 141.3 (C), 141.0 (C), 135.6 (C), 133.2 (C), $133.0(\mathrm{CH}), 129.8(\mathrm{CH}), 128.8(\mathrm{CH}), 127.9(\mathrm{CH}), 127.7(\mathrm{CH}), 127.5$ $(\mathrm{CH}), 127.2(\mathrm{CH}), 127.0(\mathrm{CH}), 126.4(\mathrm{CH}), 126.1(\mathrm{CH}), 125.8(\mathrm{CH})$, $125.3(\mathrm{CH}), 124.8(\mathrm{CH}), 124.7(\mathrm{CH}), 124.5(\mathrm{CH}), 124.4(\mathrm{CH}), 120.7$ (CH), 120.5 (CH), 118.8 (C), 118.4 (C), 116.9 (C), 114.3 (C), 110.8 (CN), $37.5\left(\mathrm{CH}_{2}\right)$ ppm. Elemental analysis: calcd for $\mathrm{C}_{41} \mathrm{H}_{23} \mathrm{~N}_{3} \mathrm{O}_{2}$ : C, 83.52; H, 3.93; N, 7.13; found: C, 83.44; H, 3.79; N, 7.01.

6-(9H-Fluoren-2-yl)-4-(4-nitrophenyl)-2-(pyren-1-yl) nicotinonitrile (8f). Yellow crystals; yield (94\%), $\mathrm{mp} 299-300{ }^{\circ} \mathrm{C}$. FT-IR (KBr): $\nu_{\max }=3041$ (CH arom.), $2199(\mathrm{CN}), 1610(\mathrm{C}=$ N) $\mathrm{cm}^{-1} \cdot{ }^{1} \mathrm{H} \mathrm{NMR}\left(\mathrm{CDCl}_{3}\right): \delta=8.50(\mathrm{~d}, J=7.5 \mathrm{~Hz}, 1 \mathrm{H}), 8.46(\mathrm{~s}$, $1 \mathrm{H}), 8.38(\mathrm{~s}, 1 \mathrm{H}), 8.31-8.27(\mathrm{~m}, 4 \mathrm{H}), 8.21-8.19(\mathrm{~m}, 4 \mathrm{H}), 8.11-8.08$ $(\mathrm{m}, 3 \mathrm{H}), 8.03-8.01(\mathrm{~m}, 2 \mathrm{H}), 7.94-7.92(\mathrm{~m}, 1 \mathrm{H}), 7.89-7.87(\mathrm{~m}$, 1H), 7.61-7.59 (m, 1H), 7.45-7.39 (m, 2H), $3.99(\mathrm{~s}, 2 \mathrm{H}$, $\left.\mathrm{CH}_{2}\right)$ ppm. ${ }^{13} \mathrm{C} \mathrm{NMR}\left(\mathrm{CDCl}_{3}\right): \delta=161.1(\mathrm{C}=\mathrm{N}), 161.0(\mathrm{C}), 159.8$ (C), 148.7 (C), 147.9 (C), 144.7 (C), 144.1 (C), 140.6 (C), 135.3 (C), $132.6(\mathrm{C}), 130.8(\mathrm{C}), 130.2(\mathrm{CH}), 129.2(\mathrm{CH}), 129.0(\mathrm{CH}), 128.1$ $(\mathrm{CH}), 127.7(\mathrm{CH}), 127.4(\mathrm{CH}), 127.1(\mathrm{CH}), 126.6(\mathrm{CH}), 126.3(\mathrm{CH})$, $125.9(\mathrm{CH}), 125.5(\mathrm{CH}), 124.9(\mathrm{CH}), 124.8(\mathrm{CH}), 124.6(\mathrm{CH}), 124.5$ $(\mathrm{CH}), 120.9(\mathrm{CH}), 120.7(\mathrm{CH}), 118.6(\mathrm{CH}), 118.2(\mathrm{C}), 106.9(\mathrm{CN})$, $37.0\left(\mathrm{CH}_{2}\right)$ ppm. Elemental analysis: calcd for $\mathrm{C}_{42} \mathrm{H}_{23} \mathrm{~N}_{3}: \mathrm{C}$, 88.55; H, 4.07; N, 7.38; found: C, 88.60; H, 4.15; N, 7.30.

\section{Conflicts of interest}

The authors confirm that there are no conflicts of interest to disclose.

\section{Acknowledgements}

The authors are highly indebted to the Deanship of the Scientific Research (DSR), Umm Al-Qura University for the full financial support of this work through the project number 18SCI-1-01-0009. S. A. Ahmed is highly indebted to the Alexander von Humboldt Foundation (AvH) and Prof. Jochen Mattay, Bielefeld University, Germany for help with some of the analytical and spectroscopic measurements in addition to some labware donations.

\section{Notes and references}

1 L. F. Tietze, Chem. Rev., 1996, 96, 115-136.

2 I. Ugi, A. Dömling and W. Hörl, Endeavour, 1994, 18, 115122. 
3 A. Dömling, W. Wang and K. Wang, Chem. Rev., 2012, 112, 3083-3135.

4 S. Tu, B. Jiang, Y. Zhang, R. Jia, J. Zhang, C. Yao and F. Shi, Org. Biomol. Chem., 2007, 5, 355-359.

5 C. B. Reddy, K. S. Kumar, M. A. Kumar, M. V. N. Reddy, B. S. Krishna, M. Naveen, M. K. Arunasree, C. S. Reddy, C. N. Raju and C. D. Reddy, Eur. J. Med. Chem., 2012, 47, 553-559.

6 J. A. Wells and C. L. McClendon, Nature, 2007, 450, 10011009.

7 Y. Feng, T. J. Mitchison, A. Bender, D. W. Young and J. A. Tallarico, Nat. Rev. Drug Discovery, 2009, 8, 567-578.

8 V. Azzarito, K. Long, N. S. Murphy and A. J. Wilson, Nat. Chem., 2013, 5, 161-173.

9 J. M. Grasshoff, J. L. Marshall, R. A. Minns, S. M. Ramos, S. G. Stroud, S. J. Telfer, H. Yang, R. A. Boggs and E. S. Kolb, Process and composition for generating acid for imaging compositions, Int. Pat., 9824000, June 4, 1998.

10 N. Hisamatsu and S. Hiraishi, Thermal recording material providing yellow image, Japanese Pat., 10250237, September 22, 1998.

11 C. S. Angadiyavar and R. Srinivasan, 2,4,6-Trisubstituted pyridine dye lasers, US. Pat., 506916, February 3, 1976.

12 B. Garcia-Acosta, R. Martinez-Manez, F. Sancenon, J. Soto, K. Rurack, M. Spieles, E. Garcia-Breijo and L. Gil, Inorg. Chem., 2007, 46, 3123-3135.

13 B. Tang, F. Yu, P. Li, L. Tong, X. Duan, T. Xie and X. Wang, J. Am. Chem. Soc., 2009, 131, 3016-3023.

14 C. Z. Wang, X. Feng, Z. Kowsera, C. Wu, T. Akther, M. R. J. Elsegood, C. Redshaw and T. Yamato, Dyes Pigm., 2018, 153, 125-131.

15 J. Hu, M. Era, M. R. J. Elsegood and T. Yamato, Eur. J. Org. Chem., 2010, 72-79.

16 M. Ottonelli, M. Piccardo, D. Duce, S. Thea and G. Dellepiane, J. Phys. Chem. A, 2012, 116, 611-630.

17 D. G. Vanga, M. Santra, A. Keerthi and S. Valiyaveettil, Org. Biomol. Chem., 2014, 12, 7914-7918.

18 P. S. Reeta, A. Khetubol, T. Jella, V. Chukharev, F. AbouChahine, N. V. Tkachenko, L. Giribabu and H. Lemmetyinen, J. Porphyrins Phthalocyanines, 2015, 19, 288-300.

19 M. Nandakumar, E. Sankar and A. K. Mohanakrishnan, Synth. Commun., 2016, 46, 1810-1819.

20 C. Z. Wang, R. Kihara, X. Feng, P. Thuéry, C. Redshaw and T. Yamato, ChemistrySelect, 2017, 2, 1436-1441.

21 W. Yang, J. H. S. K. Monteiro, A. de Bettencourt-Dias and W. A. Chalifoux, Can. J. Chem., 2017, 95, 341-345.

22 J. Weng, Q. Mei, Q. Q. Ling, Q. Fan and W. Huang, Tetrahedron, 2012, 68, 3129-3134.

23 J. S. Yang, C. S. Lin and C. Y. Huang, Org. Lett., 2001, 3, 889892.

24 S. K. Kim, J. H. Bok, R. A. Bartsch, J. Y. Lee and J. S. Kim, Org. Lett., 2005, 7, 4839-4842.

25 T. C. Chou, C. L. Hwa, J. J. Lin, K. C. Liao and J. C. Tseng, J. Org. Chem., 2005, 70, 9717-9726.

26 F. Gualtieri, E. Teodori, C. Bellucci, E. Pesce and G. Piacenza, J. Med. Chem., 1985, 28, 1621-1628.
27 C. A. Parker, Photoluminescence of Solutions, Elsevier, Amsterdam, the Netherlands, 1968.

28 S. R. Marder, B. Kippelen, A. K. Y. Jen and N. Peyghammbarian, Nature, 1997, 388, 845-851.

29 R. H. Friend, R. W. Gymer, A. B. Holmes, J. H. Burroughes, R. N. Marks, C. Taliani, D. D. C. Bradley, D. A. Dos Santos, J. L. Bredas, M. Logdlund and W. R. Salaneck, Nature, 1999, 397, 121-128.

30 J. Jo, C. Chi, S. Hoeger, G. Wegner and D. Y. Yoon, Chem. Eur. J., 2004, 10, 2681-2688.

31 P. Thirumurugan and P. T. Perumal, Tetrahedron, 2009, 65, 7620-7629.

32 K. Zhao, X.-P. Xu, S.-L. Zhu, D.-Q. Shi, Y. Zhang and S.-J. Ji, Synthesis, 2009, 16, 2697-2708.

33 F. Zhang, Y. Zhao, L. Sun, L. Ding, Y. Gu and P. Gong, Eur. J. Med. Chem., 2011, 46, 3149-3157.

34 N. S. El-Sayed, A. N. Shirazi, M. G. El-Meligy, A. K. El-Ziaty, D. Rowley, J. Sun, Z. A. Nagib and K. Parang, Tetrahedron Lett., 2014, 55, 1154-1158.

35 E. E. Sizova, E. V. Arshinov, Y. A. Kotsareva, L. V. Glizdinskaya and G. P. Sagitullina, Chem. Heterocycl. Compd., 2017, 53, 1026-1032.

36 K. A. M. Abouzid, G. H. Al-Ansary and A. M. El-Naggar, Eur. J. Med. Chem., 2017, 134, 357-365.

37 S. K. Krishnammagari, S. G. Balwe, J. S. Kim, K. T. Lim and Y. T. Jeong, Monatsh. Chem., 2019, 150, 691-702.

38 E. M. Hussein, Z. Moussa, N. El Guesmi and S. A. Ahmed, RSC Adv., 2018, 8, 24116-24127.

39 N. El Guesmi, E. M. Hussein and S. A. Ahmed, J. Photochem. Photobiol., A, 2019, 371, 306-314.

40 E. M. Hussein, Z. Naturforsch. B Chem. Sci, 2012, 67, 231-237.

41 E. M. Hussein and A. M. El-Khawaga, J. Heterocycl. Chem., 2012, 49, 1296-1301.

42 E. M. Hussein, Monatsh. Chem., 2013, 144, 1691-1697.

43 E. M Hussein, Russ. J. Org. Chem., 2015, 51, 54-64.

44 E. M. Hussein and S. A. Ahmed, Chem. Heterocycl. Compd., 2017, 53, 1148-1155.

45 (a) M. Barfield and D. M. Grant, J. Am. Chem. Soc., 1961, 83, 4726-4729; (b) J. A. Pople and A. A. Bothner, J. Chem. Phys., 1965, 42, 1339-1349; (c) R. C. Cookson, T. A. Crabb, J. J. Frankel and J. Hudec, Tetrahedron, 1966, 22, 355-390; (d) R. Cahill, R. C. Cookson and T. A. Crabb, Tetrahedron, 1969, 25, 4681-4709.

46 H. M. Manohara, C. T. Devaiah, B. Hemavathi and T. N. Ahipa, J. Lumin., 2019, 206, 284-291.

47 H. A. El-Sayed, A. M. Abdel Hamid, S. M. Mohammed and A. H. Moustafa, Synth. Commun., 2019, 49, 2096-2105.

48 O. V. Ershov, S. V. Fedoseev, M. Y. Ievlev and M. Y. Belikov, Dyes Pigm., 2016, 134, 459-464.

49 C.-S. Yao, K. Lu, B. Song, B. Liu, T.-J. Li and C.-X. Yub, J. Heterocycl. Chem., 2014, 51, 1807-1810.

50 T. N. Ahipa, V. Kumar and A. V. Adhikari, Struct. Chem., 2014, 25, 1165-1174.

51 E. P. Gutiérrez, M. J. Percino, V. M. Chapela, M. Cerón, J. L. Maldonado and G. R. Ortiz, Materials, 2011, 4, 562-574. 52 M. D. Bowman, M. M. Jacobson and H. E. Blackwell, Org. Lett., 2006, 8, 1645-1648. 
53 S. J. J. Titinchi, F. S. Kamounah, H. S. Abbo and O. Hammerich, ARKIVOC, 2008, 13, 91-105.

54 E. M. Hussein, S. A. Ahmed and I. I. Althagafi, Heterocycl. Commun., 2017, 23, 379-384.

55 D. W. Robertson, J. H. Krushinski, E. E. Beedle, J. D. Leander, D. T. Wong and R. C. Rathbun, J. Med. Chem., 1986, 29, 1577-1586.
56 P. G. Baraldi, R. Romagnoli, M. G. Pavani, M. Nuñez, M. A. Tabrizi, J. C. Shryock, E. Leung, A. R. Moorman, C. Uluoglu, V. Iannotta, S. Merighi and P. A. Borea, J. Med. Chem., 2003, 46, 794-809. 